\section{A) Check for updates}

Cite this: Dalton Trans., 2017, 46, 7844

\title{
Stable Au'II complexes with four N-heterocyclic carbene groups can be prepared in high yield directly from $\mathrm{KAuCl}_{4} \dagger$
}

\begin{abstract}
Ahmed H. Mageed, ${ }^{a, b}$ Brian W. Skelton ${ }^{a, c}$ and Murray V. Baker (D) *a
Gold(III) N-heterocyclic carbene (NHC) complexes of form $\left[\mathrm{Au}(\mathrm{NHC})_{4} \mathrm{Cl}_{2}\right] \mathrm{Cl}$ were synthesized by reaction of $\mathrm{KAuCl}_{4}$ with bis- and tetrakis(imidazolium) salts in the presence of a mild base. Treatment of these complexes with $\mathrm{KPF}_{6}$ afforded four-coordinate $\mathrm{Au}^{\prime \prime \prime}$ complexes of form [Au(NHC$\left.)_{4}\right]\left(\mathrm{PF}_{6}\right)_{3}$. X-Ray crystallography showed the $\left[\mathrm{Au}^{\prime \prime \prime}(\mathrm{NHC})_{4}\right]^{3+}$ cations in the hexafluorophosphate salts to have a square planar $\mathrm{Au}(\mathrm{NHC})_{4}$ moiety $\left[\mathrm{Au} \cdots \mathrm{C}_{\mathrm{NHC}} 2.024(4)-2.082(7) \AA \AA\right]$. In the $\left[\mathrm{Au}^{\prime \prime \prime}\left(\mathrm{NHC}_{4} \mathrm{Cl}_{2}\right]^{+}\right.$cations in the chloride salts, coordination about Au was tetragonally-distorted octahedral, the axial $\mathrm{Au}-\mathrm{Cl}$ bonds being substantially

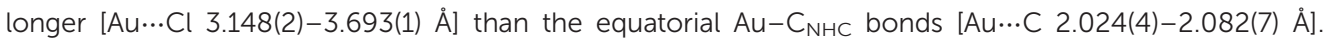
NMR and conductance studies suggested that the structures of the complexes seen in the solid state persisted in DMSO solution, except in one case where a chlorido ligand dissociated from $\left[\mathrm{Au}^{\mathrm{III}}\left(\mathrm{NHC}_{4} \mathrm{Cl}_{2}\right]^{+}\right.$to form $\left[\mathrm{Au}^{\prime \prime \prime}(\mathrm{NHC})_{4} \mathrm{Cl}\right]^{2+}$. The $\mathrm{Au}^{\prime \prime \prime \prime}\left(\mathrm{NHC}_{4}\right.$ unit was surprisingly robust. An Au complex was found to undergo $\mathrm{H} / \mathrm{D}$ exchange reactions in $\mathrm{D}_{2} \mathrm{O}$ solution at $100^{\circ} \mathrm{C}$ with no signs of decomposition detectable by ${ }^{1} \mathrm{H}$ NMR spectroscopy. ${ }^{1} \mathrm{H}$ NMR studies showed that various complexes containing $\mathrm{Au}^{\prime \prime \prime}(\mathrm{NHC})_{4}$ moieties underwent little or no decomposition when heated at $120^{\circ} \mathrm{C}$ in DMSO- $d_{6}$ for extended periods.
\end{abstract}

Received 10th April 2017,

Accepted 1st June 2017

DOI: $10.1039 / \mathrm{c} 7 \mathrm{dt} 01272 \mathrm{a}$

rsc.li/dalton tions during which reduction of $\mathrm{Au}^{\mathrm{III}}$ occurs. ${ }^{8-12}$ Not surprisingly, the most common synthetic pathway to $\mathrm{Au}^{\mathrm{III}}-\mathrm{NHC}$ complexes involves oxidative addition of halogens or halogen equivalents to $\mathrm{Au}^{\mathrm{I}}-\mathrm{NHC}$ precursor complexes. ${ }^{8,9,13-31}$ Other procedures, such as carbene transfer between $\mathrm{Ag}^{\mathrm{I}}$ and $\mathrm{Au}^{\mathrm{III}},{ }^{8}$ or reaction of imidazolium ions with $\mathrm{Au}^{\mathrm{III}}$ in the presence of base, ${ }^{9,10}$ are usually complicated by reduction of $\mathrm{Au}^{\mathrm{III}}$ to $\mathrm{Au}^{\mathrm{I}}$. However, $\mathrm{Lu}$ et al. synthesized the $\mathrm{Au}^{\mathrm{III}}$-tetracarbene complex $\mathbf{1}$ by treatment of $\mathrm{HAuCl}_{4}$ with an $\mathrm{Ag}^{\mathrm{I}}-\mathrm{NHC}$ complex. ${ }^{32}$ Most $\mathrm{Au}^{\mathrm{III}}-\mathrm{NHC}$ complexes reported to date have square-planar $\mathrm{Au}^{\mathrm{III}}$ centres with one or two NHC ligands, 1 being the only $\mathrm{Au}(\mathrm{NHC})_{4}$ motif reported to date. While the $\mathrm{Au}^{\mathrm{III}}$ centre in $\mathbf{1}$ is square planar, many complexes of $\mathrm{Au}^{\text {III }}$ with other ligands contain square pyramidal and octahedral $\mathrm{Au}$ centres (e.g. $\left[\mathrm{Au}(\right.$ phen $\left.)(\mathrm{CN})_{2} \mathrm{Br}\right]$ and $[\mathrm{Au}$ $\left.(\text { diars })_{2} \mathrm{I}_{2}\right]^{+}$), albeit strongly distorted, the axial metal-ligand bonds being longer than the equatorial ones. ${ }^{33,34}$

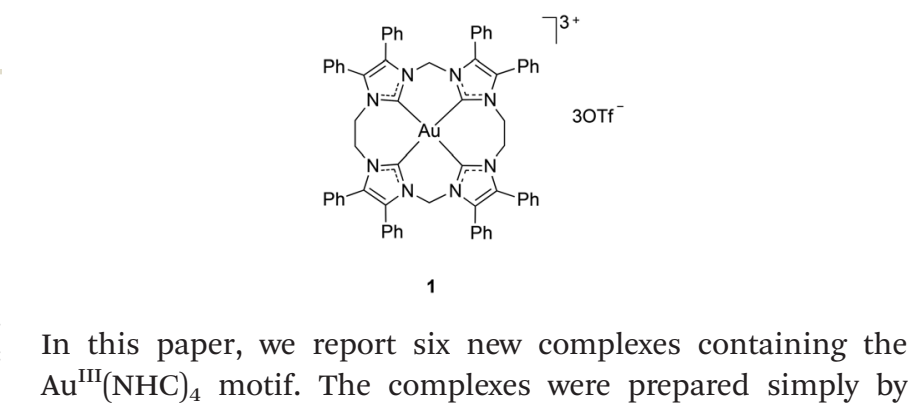

In this paper, we report six new complexes containing the $\mathrm{Au}^{\mathrm{III}}(\mathrm{NHC})_{4}$ motif. The complexes were prepared simply by

\footnotetext{
${ }^{a}$ School of Molecular Sciences M310, The University of Western Australia, 35 Stirling Highway, Perth,WA6009, Australia. E-mail: murray.baker@uwa.edu.au

${ }^{b}$ Department of Chemistry, Faculty of Science, The University of Kufa, P.O. Box 21, Najaf 54001, Iraq

${ }^{c}$ Centre for Microscopy, Characterisation and Analysis M310, The University of Western Australia, Perth, WA 6009, Australia.

$\dagger$ Electronic supplementary information (ESI) available. CCDC 1528857-1528862. For ESI and crystallographic data in CIF or other electronic format see DOI $10.1039 / \mathrm{c} 7 \mathrm{dt} 01272 \mathrm{a}$
} 
treatment of $\mathrm{KAuCl}_{4}$ with imidazolium salts in the presence of acetate. Depending on the ancillary ligands, the new complexes contain four- or six-coordinate $\mathrm{Au}^{\mathrm{III}}$ centres, and all have been thoroughly characterised by NMR and X-ray studies.

\section{Results and discussion}

\section{Synthesis of $\mathrm{Au}^{\mathrm{III}}-\mathrm{NHC}$ complexes}

$\mathrm{Au}^{\mathrm{III}}$-NHC chlorido complexes $\left[\mathrm{Au}\left(\mathbf{L}^{\mathbf{1}}\right)_{2} \mathrm{Cl}_{2}\right] \mathrm{Cl} 2,\left[\mathrm{Au}\left(\mathbf{L}^{2}\right)_{2} \mathrm{Cl}_{2}\right] \mathrm{Cl}$ 3, and $\left[\mathrm{AuL}^{3} \mathrm{Cl}_{2}\right] \mathrm{Cl} 4$ (Scheme 1) were synthesized by heating $\mathrm{KAuCl}_{4}$ with the appropriate imidazolium salt and LiOAc in DMF, following procedures we used previously to synthesize $\mathrm{Au}^{\mathrm{I}}$-NHC cyclophane complexes. ${ }^{1}$ The complexes $\left[\mathrm{Au}\left(\mathbf{L}^{\mathbf{1}}\right)_{2} \mathrm{Cl}_{2}\right]$ $\mathrm{Cl} \mathrm{2,}\left[\mathrm{Au}\left(\mathbf{L}^{2}\right)_{2} \mathrm{Cl}_{2}\right] \mathrm{Cl} 3$ and $\left[\mathrm{AuL}^{3} \mathrm{Cl}_{2}\right] \mathrm{Cl} 4$ precipitated from the mixture and were purified by recrystallisation; yields after recrystallisation were 81,79 , and $48 \%$ respectively. These yields are surprisingly high, as previous attempts so synthesize $\mathrm{Au}^{\mathrm{III}}$-NHC complexes by reaction of imidazolium salts with $\mathrm{Au}^{\mathrm{III}}$ salts in the presence of base were accompanied by a substantial amount of reduction of $\mathrm{Au}^{\mathrm{III}}$ to $\mathrm{Au}^{\mathrm{I}},{ }^{9,10}$ the problem being exacerbated by long reaction times. ${ }^{10}$ We attribute these high yields in part to remarkable stability of the $\mathrm{Au}^{\mathrm{III}}$-tetrakis (NHC) complexes (see NMR studies, below). Interestingly, the $\left[\mathrm{Au}(\mathrm{NHC})_{4} \mathrm{Cl}_{2}\right] \mathrm{Cl}$ structure seems to be the preferred product even when the stoichiometry is unfavourable-when we allowed $\mathbf{L}^{\mathbf{1}} \cdot 2 \mathrm{HCl}$ and $\mathrm{KAuCl}_{4}$ to react in a $1: 1$ mole ratio in the presence of excess LiOAc, the only product obtained was $\left[\mathrm{Au}\left(\mathbf{L}^{\mathbf{1}}\right)_{2} \mathrm{Cl}_{2}\right] \mathrm{Cl} \mathbf{2}\left(86 \%\right.$ yield based on $\left.\mathbf{L}^{\mathbf{1}} \cdot 2 \mathrm{HCl}\right)$. The structure of the starting imidazolium salt (i.e., whether it contains a mono-, bis-, or tetrakis(imidazolium) ion) is also an important factor in determining the outcome of the reactions. The use bis- or tetrakis(imidazolium) salts as precursors makes formation of the $\mathrm{Au}^{\mathrm{III}}(\mathrm{NHC})_{4}$ moiety kinetically favourable compared to competing processes in which $\mathrm{Au}(\mathrm{III})$ participates in redox reactions. When we attempted syntheses using simple monoimidazolium salts (1,3-dimethylimidazolium iodide and 1,3-diisopropylimidazolium bromide), we did not obtain any
$\mathrm{Au}^{\mathrm{III}}(\mathrm{NHC})_{4}$-type complex, instead obtaining small amounts of $\left[(\mathrm{NHC}) \mathrm{AuX}_{3}\right], \mathrm{Au}^{\mathrm{I}}-\mathrm{NHC}$ complexes, and the urea-type product of oxidation of the imidazolium ion at $\mathrm{C} 2$. Other researchers have also reported poor results from attempts to synthesize $\mathrm{Au}^{\mathrm{III}}$ complexes directly from monoimidazolium ions and $\mathrm{Au}^{\mathrm{III}}$ salts in the presence of base. ${ }^{9,10}$

The $\mathrm{PF}_{6}{ }^{-}$salts $\left[\mathrm{Au}\left(\mathbf{L}^{\mathbf{1}}\right)_{2}\right]\left(\mathrm{PF}_{6}\right)_{3} \quad \mathbf{5},\left[\mathrm{Au}\left(\mathbf{L}^{2}\right)_{2}\right]\left(\mathrm{PF}_{6}\right)_{3} \quad \mathbf{6}$, and $\left[\mathrm{AuL}^{3}\right]\left(\mathrm{PF}_{6}\right)_{3} 7$ were obtained from the corresponding chlorides $\left[\mathrm{Au}\left(\mathbf{L}^{\mathbf{1}}\right)_{2} \mathrm{Cl}_{2}\right] \mathrm{Cl} 2,\left[\mathrm{Au}\left(\mathbf{L}^{2}\right)_{2} \mathrm{Cl}_{2}\right] \mathrm{Cl} \mathrm{3}$, and $\left[\mathrm{AuL}^{3} \mathrm{Cl}_{2}\right] \mathrm{Cl} \mathbf{4}$ respectively, by metathesis with $\mathrm{KPF}_{6}$ in methanol, and were obtained as analytically-pure, white powders, in quantitative yields.

\section{X-ray studies}

Results of X-ray diffraction studies of the $\mathrm{Au}^{\mathrm{III}}$ complexes are summarized in Tables 1 and 2 and Fig. 1-3. The chlorido complexes $\left[\mathrm{Au}\left(\mathbf{L}^{\mathbf{1}}\right)_{2} \mathrm{Cl}_{2}\right]^{+},\left[\mathrm{Au}\left(\mathbf{L}^{2}\right)_{2} \mathrm{Cl}_{2}\right]^{+}$and $\left[\mathrm{AuL}^{3} \mathrm{Cl}_{2}\right]^{+}$each contain an $\mathrm{Au}^{\mathrm{III}}$ centre in a strongly distorted octahedral environment, and are examples of rarely-encountered 20-electron complexes. Removal of the chlorido ligands results in $\left[\mathrm{Au}\left(\mathbf{L}^{\mathbf{1}}\right)_{2}\right]^{3+},\left[\mathrm{Au}\left(\mathbf{L}^{2}\right)_{2}\right]^{3+}$ and $\left[\mathrm{AuL}^{3}\right]^{3+}$, which might be thought of as structures containing commonly encountered four-coordinate $\mathrm{Au}^{\text {III }}$ centres (16-electron complexes), but the picture is complicated by fluorines from $\mathrm{PF}_{6}{ }^{-}$anions occupying axial coordination sites.

In each of the six complexes, the NHC units comprise an approximate square planar array around the $\mathrm{Au}^{\mathrm{III}}$ centre. $\mathrm{Au}-\mathrm{C}$ distances are in the range 2.024(4)-2.082(7) $\AA$ across the series of complexes, and are similar to the values seen for other complexes of form $\left[\mathrm{Au}^{\mathrm{III}}(\mathrm{NHC})_{4}\right]^{3+}(\mathbf{1}$ in Table 2$){ }^{32}\left[\mathrm{Au}^{\mathrm{III}}(\mathrm{NHC})-\right.$ (halide $\left.)_{3}\right],,^{8,35}$ and $\left[\mathrm{Au}^{\mathrm{III}}(\mathrm{NHC})_{2}(\text { halide })_{2}\right]^{+} .^{8,13,35} \mathrm{In}\left[\mathrm{Au}\left(\mathbf{L}^{\mathbf{1}}\right)_{2} \mathrm{Cl}_{2}\right]_{-}$ $\mathrm{Cl} \cdot(\mathrm{MeOH})_{2} 2 \cdot(\mathrm{MeOH})_{2},\left[\mathrm{Au}\left(\mathbf{L}^{2}\right)_{2} \mathrm{Cl}_{2}\right] \mathrm{Cl} \cdot(\mathrm{MeOH}) 3 \cdot(\mathrm{MeOH})$, and $\left[\mathrm{AuL}^{3} \mathrm{Cl}_{2}\right] \mathrm{Cl} \cdot(\mathrm{MeOH})_{3.5} \quad \mathbf{4} \cdot(\mathrm{MeOH})_{3.5}$, two $\mathrm{Cl}^{-}$ligands occupy additional (axial) coordination sites, $\mathrm{Au}-\mathrm{Cl}_{\text {axial }}$ being in the range 3.148(2)-3.693(1) $\AA$, so that overall coordination geometry is distorted octahedral. These $\mathrm{Au}-\mathrm{Cl}_{\text {axial }}$ bond distances are about $0.9 \AA$ longer than $\mathrm{Au}-\mathrm{Cl}_{\text {equatorial }}(\sim 2.27 \AA)$ bond lengths seen in $\left[\mathrm{Au}(\mathrm{HHCT}) \mathrm{Cl}_{2}\right] \mathrm{AuCl}_{4}$ (HHCT = 1,8-bis(hydroxyethyl)-1,3,6,8,10,13-hexaazacyclotetradec-ane), [Au(dien)C1 $\left.1_{3}\right]$ $($ dien $=$ diethylenetriamine $)$, etc.,$^{36-38}$ but are much shorter

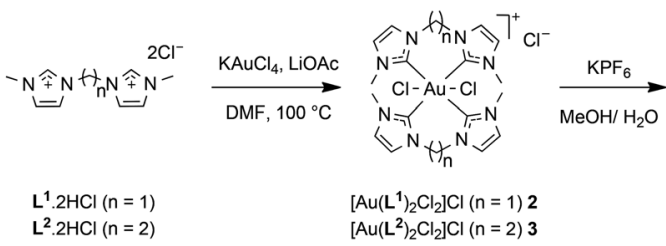

$\left[\mathrm{Au}\left(\mathrm{L}^{2}\right)_{2} \mathrm{Cl}_{2}\right] \mathrm{Cl}(\mathrm{n}=2) 3$

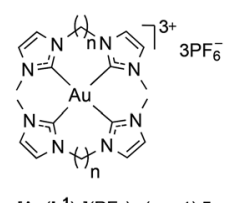

$\left[\mathrm{Au}\left(\mathrm{L}^{1}\right)_{2}\right]\left(\mathrm{PF}_{6}\right)_{3}(\mathrm{n}=1) 5$ $\left[\mathrm{Au}\left(\mathrm{L}^{2}\right)_{2}\right]\left(\mathrm{PF}_{6}\right)_{3}(\mathrm{n}=2) 6$
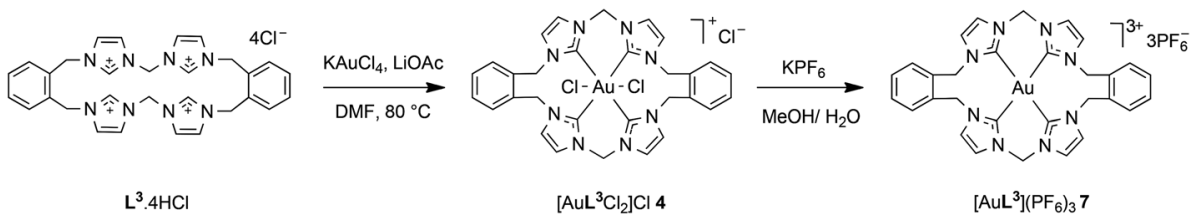

Scheme 1 Synthesis of Au'II-NHC complexes. 
Table 1 Crystal data of new Aull' compounds

\begin{tabular}{|c|c|c|c|c|c|c|}
\hline Complex & $\begin{array}{l}{\left[\mathrm{AuL} \mathbf{L}^{\mathbf{1}} \mathrm{Cl}_{2}\right]} \\
\mathrm{Cl} \cdot(\mathrm{MeOH})_{2} 2\end{array}$ & $\begin{array}{l}{\left[\mathrm{AuL}^{2} \mathrm{Cl}_{2}\right]} \\
\mathrm{Cl} \cdot(\mathrm{MeOH}) 3\end{array}$ & $\begin{array}{l}{\left[\mathrm{AuL} \mathbf{L}^{3} \mathrm{Cl}_{2}\right] \mathrm{Cl} \cdot} \\
(\mathrm{MeOH})_{3.5} \mathbf{4}\end{array}$ & $\begin{array}{l}{\left[\mathrm{AuL}^{\mathbf{1}}\right]\left(\mathrm{PF}_{6}\right)_{3} .} \\
(\mathrm{MeCN})_{2} \mathbf{5}\end{array}$ & $\begin{array}{l}{\left[\mathrm{AuL}^{2}\right]\left(\mathrm{PF}_{6}\right)_{3} .} \\
(\mathrm{MeCN})_{2} 6\end{array}$ & $\begin{array}{l}{\left[\mathrm{AuL}^{3}\right]\left(\mathrm{PF}_{6}\right)_{3} .} \\
(\mathrm{MeCN})_{2} 7\end{array}$ \\
\hline $\begin{array}{l}\text { Empirical } \\
\text { formula }\end{array}$ & $\mathrm{C}_{20} \mathrm{H}_{32} \mathrm{AuCl}_{3} \mathrm{~N}_{8} \mathrm{O}_{2}$ & $\mathrm{C}_{21} \mathrm{H}_{32} \mathrm{AuCl}_{3} \mathrm{~N}_{8} \mathrm{O}$ & $\mathrm{C}_{33.50} \mathrm{H}_{42} \mathrm{AuCl}_{3} \mathrm{~N}_{8} \mathrm{O}_{3.50}$ & $\mathrm{C}_{22} \mathrm{H}_{30} \mathrm{AuF}_{18} \mathrm{~N}_{10} \mathrm{P}_{3}$ & $\mathrm{C}_{24} \mathrm{H}_{34} \mathrm{AuF}_{18} \mathrm{~N}_{10} \mathrm{P}_{3}$ & $\mathrm{C}_{34} \mathrm{H}_{34} \mathrm{AuF}_{18} \mathrm{~N}_{10} \mathrm{P}_{3}$ \\
\hline Formula weight & 719.85 & 715.86 & 916.07 & 1066.43 & 1094.49 & 1214.59 \\
\hline Wavelength/A & 0.71073 & 0.71073 & 1.54184 & 0.71073 & 0.71073 & 0.71073 \\
\hline Crystal system & Monoclinic & Monoclinic & Monoclinic & Monoclinic & Monoclinic & Triclinic \\
\hline Space group & $P 2_{1} / c$ & $P 2_{1} / c$ & $I 2 / m$ & $C 2 / c$ & $C 2 / c$ & $P \overline{1}$ \\
\hline$a / \AA$ & $11.2465(4)$ & $8.4520(3)$ & $11.5286(4)$ & $19.6697(5)$ & $19.5075(5)$ & $9.50080(10)$ \\
\hline$b / \AA$ & $12.5742(5)$ & $21.5282(5)$ & $18.4128(5)$ & $11.0832(2)$ & $11.1838(2)$ & $15.6009(2)$ \\
\hline$c / \AA$ & $18.5100(7)$ & $14.1226(4)$ & $16.9015(6)$ & $17.0857(6)$ & $18.0374(4)$ & $21.6100(3)$ \\
\hline$\alpha /{ }^{\circ}$ & & & & & & $95.646(1)$ \\
\hline$\beta /{ }^{\circ}$ & $100.893(4)$ & $101.964(3)$ & $98.985(3)$ & $113.018(4)$ & $113.442(3)$ & 96.197(1) \\
\hline$\gamma /{ }^{\circ}$ & & & & & & $94.683(1)$ \\
\hline$V / \AA^{3}$ & $2570.44(17)$ & $2513.88(13)$ & $3543.7(2)$ & $3428.18(19)$ & $3610.39(16)$ & $3155.08(7)$ \\
\hline$Z$ & 4 & 4 & 4 & 4 & 4 & 3 \\
\hline$\rho($ calc $) / \mathrm{Mg} \mathrm{m}^{-3}$ & 1.860 & 1.891 & 1.717 & 2.066 & 2.014 & 1.918 \\
\hline$\mu / \mathrm{mm}^{-1}$ & 6.070 & 6.203 & 10.284 & 4.565 & 4.338 & 3.734 \\
\hline $\begin{array}{l}\text { Crystal } \\
\text { size } / \mathrm{mm}^{3}\end{array}$ & $\begin{array}{l}0.638 \times 0.230 \times \\
0.069\end{array}$ & $\begin{array}{l}0.186 \times 0.127 \times \\
0.080\end{array}$ & $0.147 \times 0.116 \times 0.057$ & $0.48 \times 0.31 \times 0.22$ & $\begin{array}{l}0.40 \times 0.285 \times \\
0.245\end{array}$ & $\begin{array}{l}0.355 \times 0.247 \times \\
0.191\end{array}$ \\
\hline $\begin{array}{l}\theta \text { range for data } \\
\text { collection/ }{ }^{\circ}\end{array}$ & 2.455 to 27.0 & 2.463 to 32.562 & 3.574 to 67.329 & 2.276 to 37.068 & 2.147 to 37.625 & 1.708 to 30.066 \\
\hline $\begin{array}{l}\text { Reflections } \\
\text { collected }\end{array}$ & 24788 & 31630 & 17415 & 31084 & 43319 & 71746 \\
\hline $\begin{array}{l}\text { Independent } \\
\text { reflections }\end{array}$ & 14559 & 8553 & 3272 & 8533 & 9243 & 18510 \\
\hline$R($ int $)$ & 0.1079 & 0.0591 & 0.0482 & 0.0436 & 0.0423 & 0.0379 \\
\hline $\begin{array}{l}\text { Max./min. } \\
\text { transmission }\end{array}$ & 0.665 and 0.204 & 0.667 and 0.429 & 0.630 and 0.369 & 0.644 and 0.417 & 0.504 and 0.357 & $1.000 / 0.741$ \\
\hline $\begin{array}{l}\text { Restraints/ } \\
\text { parameters }\end{array}$ & $0 / 315$ & $0 / 313$ & $166 / 247$ & $0 / 267$ & $12 / 415$ & $0 / 971$ \\
\hline $\begin{array}{l}\text { Goodness-of-fit } \\
\text { on } F^{2}\end{array}$ & 1.105 & 1.092 & 1.117 & 1.124 & 1.047 & 1.060 \\
\hline$R_{1}[I>2 \sigma(I)]$ & 0.0628 & 0.0460 & 0.0546 & 0.0302 & 0.0263 & 0.0252 \\
\hline $\mathrm{w} R_{2}[I>2 \sigma(I)]$ & 0.1842 & 0.0765 & 0.1430 & 0.0660 & 0.0531 & 0.0552 \\
\hline$R_{1}$ (all data) & 0.0712 & 0.0681 & 0.0691 & 0.0437 & 0.0475 & 0.0316 \\
\hline $\mathrm{w} R_{2}$ (all data) & 0.1887 & 0.0819 & 0.1541 & 0.0711 & 0.0604 & 0.0576 \\
\hline $\begin{array}{l}\Delta \rho(\max / \mathrm{min}) / \\
\mathrm{e} \AA^{-3}\end{array}$ & 4.765 and -2.329 & 2.330 and -0.797 & 2.749 and -2.259 & 2.244 and -1.084 & 1.443 and -1.440 & 2.804 and -0.744 \\
\hline CCDC number & 1528857 & 1528858 & 1528859 & 1528860 & 1528861 & 1528862 \\
\hline
\end{tabular}

than the sum of the van der Waals radii of the atoms $(\sim 4.1 \AA$ for $\mathrm{Au} \cdots \mathrm{Cl}) .^{39}$ This type of distorted octahedral structural motif has been reported ${ }^{34,36,38,40}$ in only a few cases for $\mathrm{Au}^{\text {III }}$ (Table $\mathrm{S} 1 \dagger$ ), and is presumably a consequence of these complexes being 20 electron complexes. For $\left[\mathrm{AuL}^{3} \mathrm{Cl}_{2}\right] \mathrm{Cl} \cdot(\mathrm{MeOH})_{3.5}$ 4. $(\mathrm{MeOH})_{3.5}$, the coordination of $\mathrm{Au}^{\mathrm{III}}$ is broadly similar to that seen in $\left[\mathrm{Au}\left(\mathbf{L}^{\mathbf{1}}\right)_{2} \mathrm{Cl} \mathrm{l}_{2}\right] \mathrm{Cl} \cdot(\mathrm{MeOH})_{2} \mathbf{2} \cdot(\mathrm{MeOH})_{2}$ and $\left[\mathrm{Au}\left(\mathbf{L}^{2}\right)_{2} \mathrm{Cl}_{2}\right]-$ $\mathrm{Cl} \cdot(\mathrm{MeOH}) 3 \cdot(\mathrm{MeOH})$, but is complicated by the effects of solvation, the axial sites modelled as being partially occupied by chlorido ligands and solvent (methanol) molecules.

$\left[\mathrm{Au}\left(\mathbf{L}^{\mathbf{1}}\right)_{2}\right]\left(\mathrm{PF}_{6}\right)_{3} \cdot(\mathrm{MeCN})_{2} \mathbf{5} \cdot(\mathrm{MeCN})_{2}$ and $\left[\mathrm{AuL}^{3}\right]\left(\mathrm{PF}_{6}\right)_{3} \cdot(\mathrm{MeCN})_{3}$ $7 \cdot(\mathrm{MeCN})_{3}$ have similar coordination environments around $\mathrm{Au}$ to those seen in the chlorido series, but with fluorine atoms from $\mathrm{PF}_{6}{ }^{-}$groups occupying the axial coordination sites $\left(\mathrm{Au}^{\mathrm{IIII}}-\mathrm{F}\right.$ 2.92(3)-3.380(2) ̊). For $\left[\mathrm{Au}\left(\mathbf{L}^{2}\right)_{2}\right]\left(\mathrm{PF}_{6}\right)_{3} \cdot(\mathrm{MeCN})_{2} \mathbf{6} \cdot(\mathrm{MeCN})_{2}$, the coordination environment about $\mathrm{Au}^{\mathrm{III}}$ is more strictly square planar, there being only one close contact outside the square planar array $\left(\mathrm{Au}^{\mathrm{III}}-\mathrm{F}\left(\mathrm{PF}_{5}^{-}\right), 3.394(2) \AA\right)$, that contact not in a position that could be considered "axial".

In the complexes containing an $\mathrm{Au}(\mathbf{L})_{2}$ core (Fig. 1 and 2), the two bis(NHC) ligands $\left(\mathbf{L}^{\mathbf{1}}\right.$ or $\left.\mathbf{L}^{2}\right)$ are "inverted" with respect to each other (i.e., for one ligand the methylene/ethylene linker is above the $\mathrm{AuC}_{4}$ plane while for the other ligand the linker is below the $\mathrm{AuC}_{4}$ plane), presumably to avoid unfavourable intramolecular interactions between the $\mathrm{N}-\mathrm{CH}_{3}$ groups of each ligand. A similar arrangement is seen in $\left[\mathrm{AuL}^{3}\right]^{3+}$ and $\left[\mathrm{AuL}^{3} \mathrm{Cl}_{2}\right]^{+}$(Fig. 3), but here the $\mathrm{N}-\mathrm{CH}_{3}$ groups are replaced by $o$-xylylene moieties that complete the $(\mathrm{NHC})_{4}$ macrocycle. Not surprisingly, the bite angle $(\mathrm{C}(11)-\mathrm{Au}(1)-\mathrm{C}(21))$ in the complexes of $\mathbf{L}^{2}$ (NHC moieties linked by $\mathrm{CH}_{2} \mathrm{CH}_{2}$ ) is larger than for the complexes of $\mathbf{L}^{\mathbf{1}}$ (NHC moieties linked by $\mathrm{CH}_{2}$ ).

In each complex, the imidazolyl rings are tilted with respect to the $\mathrm{AuC}_{4}$ coordination plane. For all complexes of $\mathbf{L}^{\mathbf{1}}$ and $\mathbf{L}^{3}$, in which pairs of imidazolyl units are linked by a methylene bridge, the $\mathrm{AuC}_{4}$-imidazolyl interplanar angle is about $40^{\circ}$. For complexes of $\mathbf{L}^{2}$, in which the imidazolyl units are linked by a longer (ethylene) bridge, the $\mathrm{AuC}_{4}$-imidazolyl interplanar angle is higher (about $50^{\circ}$ ). This steeper inclination of the imidazolyl rings to the $\mathrm{AuC}_{4}$ plane may be the reason why the axial $\mathrm{Au}-\mathrm{L}$ bonds are longer in $\left[\mathrm{Au}\left(\mathbf{L}^{2}\right)_{2} \mathrm{Cl}_{2}\right] \mathrm{Cl} \cdot(\mathrm{MeOH}) 3 \cdot(\mathrm{MeOH})$ than in the other chloride salts, and absent in $\left[\mathrm{Au}\left(\mathbf{L}^{2}\right)_{2}\right]\left(\mathrm{PF}_{6}\right)_{3} \cdot(\mathrm{MeCN})_{2}$ 6. $(\mathrm{MeCN})_{2}-$ steric hindrance from the endo hydrogens of the 
Table 2 Selected bond lengths (Å) and angles $\left(^{\circ}\right)$ for $\mathrm{Au}^{\prime \prime \prime}$ cations ${ }^{\mathrm{a}}$

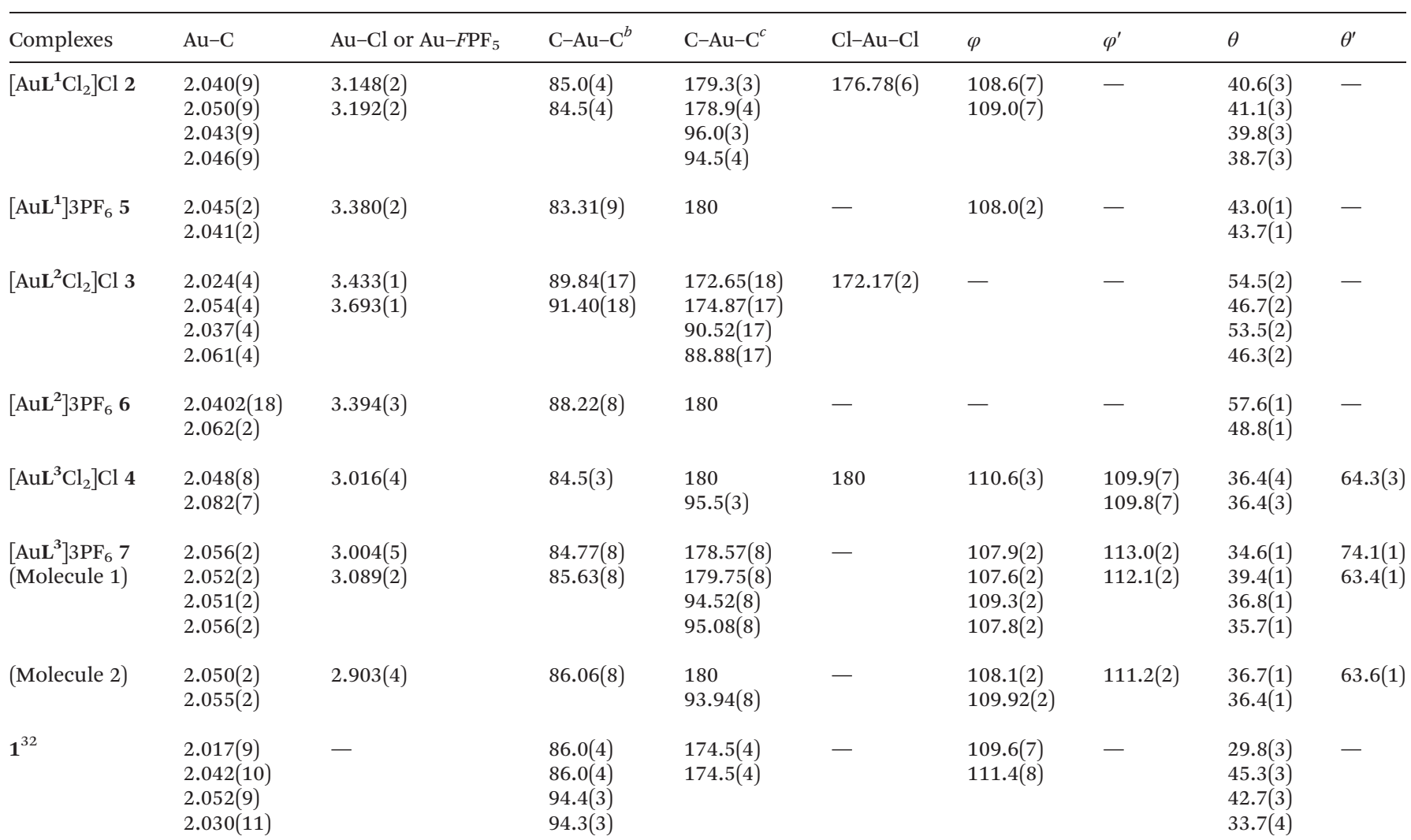

${ }^{a} \varphi=\mathrm{N}_{\mathrm{NHC}}-\mathrm{C}-\mathrm{N}_{\mathrm{NHC}} ; \varphi^{\prime}=\mathrm{N}_{\mathrm{NHC}}-\mathrm{C}-\mathrm{C}_{\text {arene }} ; \theta=\mathrm{AuC}_{4} / \mathrm{NHC}$ inter-planar angle; $\theta^{\prime}=\mathrm{AuC}_{4}$-arene inter-planar angle. ${ }^{b}$ Angle between NHCs directly linked by $\mathrm{CH}_{2}$ or $\left(\mathrm{CH}_{2}\right)_{2}$ group. ${ }^{c}$ Angle between NHCs not directly linked by $\mathrm{CH}_{2}$ or $\left(\mathrm{CH}_{2}\right)_{2}$ group.

ethylene bridge may inhibit approach of axial ligands to the Au centre.

\section{UV-vis electronic absorption spectroscopy and conductance measurements}

The UV-vis absorption spectra of all the $\mathrm{Au}^{\mathrm{III}}-\mathrm{NHC}$ complexes displayed intense absorption in the region $\lambda=230-290 \mathrm{~nm}$ (Fig. 4 and Table 3). We attribute these high energy absorption bands to $\pi-\pi^{*}$ intraligand transitions involving the NHC ligands. ${ }^{35}$ In the spectra of $\left[\mathrm{Au}\left(\mathbf{L}^{\mathbf{1}}\right)_{2} \mathrm{Cl}_{2}\right] \mathrm{Cl} 2$ and $\left[\mathrm{Au}\left(\mathbf{L}^{2}\right)_{2} \mathrm{Cl}_{2}\right] \mathrm{Cl}$ 3 (but not for $\left[\mathrm{AuL}^{3} \mathrm{Cl}_{2}\right] \mathrm{Cl} 4$ ) a weaker absorbance is observed in the region 300-350 $\mathrm{nm}$. These weaker absorption bands have energies and molar extinction coefficients ( $\varepsilon$ on the order of $10^{3}-10^{4} \mathrm{M}^{-1} \mathrm{~cm}^{-1}$ ) similar to those of ligand-to-metalcharge-transfer (LMCT) bands of the $\left[\mathrm{AuCl}_{4}\right]^{-}$ion, which has been studied in detail by Mason et al. ${ }^{41}$ Similar absorptions were also displayed by other NHC adducts of $\mathrm{Au}^{\mathrm{III}}$ halides. ${ }^{17,35}$ Therefore, we tentatively attribute these low energy absorption bands seen for $\left[\mathrm{Au}\left(\mathbf{L}^{\mathbf{1}}\right)_{2} \mathrm{Cl}_{2}\right] \mathrm{Cl} 2$ and $\left[\mathrm{Au}\left(\mathbf{L}^{2}\right)_{2} \mathrm{Cl}_{2}\right] \mathrm{Cl} 3$ to LMCTs from the chlorido ligands to the Lewis acidic $\mathrm{Au}^{\mathrm{III}}$ centres. A distinct LMCT band is not seen for $\left[\mathrm{AuL}^{3} \mathrm{Cl}_{2}\right] \mathrm{Cl} \mathbf{4}$, but may be overlapped with the high energy absorption band below $300 \mathrm{~nm}$. Similar observations were also reported by Huynh et al. for UV-vis studies of $\left[\mathrm{Au}^{\mathrm{III}} \mathrm{Cl}_{2}\left(\mathrm{iPr}_{2} \mathrm{Bim}\right)_{2}\right] \mathrm{BF}_{4}(\mathrm{Bim}=1,3-$ benzimidazol-2-ylidene). ${ }^{35}$
The molar conductance of solutions of the complexes in DMSO (Table 3) was measured to gain insight into possible dissociation of the chlorido ligands from the $\mathrm{Au}$ centres. Solutions of each of the salts $\left[\mathrm{Au}\left(\mathbf{L}^{\mathbf{1}}\right)_{2}\right]\left(\mathrm{PF}_{\mathbf{6}}\right)_{3} \mathbf{5},\left[\mathrm{Au}\left(\mathbf{L}^{\mathbf{2}}\right)_{2}\right]\left(\mathrm{PF}_{6}\right)_{3} \mathbf{6}$ and $\left[\mathrm{AuL}^{3}\right]\left(\mathrm{PF}_{6}\right)_{3} 7$, showed conductivity in the range 113-119 $\mathrm{S} \mathrm{cm} \mathrm{mol}^{-1}$. These values are in the range expected for $1: 3$ electrolytes in DMSO. ${ }^{42,43}$ By contrast, $\left[\mathrm{Au}\left(\mathbf{L}^{\mathbf{1}}\right)_{2} \mathrm{Cl}_{2}\right] \mathrm{Cl} 2$ and $\left[\mathrm{AuL}^{3} \mathrm{Cl}_{2}\right] \mathrm{Cl} 4$ showed a molar conductivity of 44.5 and $41.8 \mathrm{~S}$ $\mathrm{cm}^{2} \mathrm{~mol}^{-1}$ respectively, in the range expected for a $1: 1$ electrolyte, while $\left[\mathrm{Au}\left(\mathbf{L}^{2}\right)_{2} \mathrm{Cl}_{2}\right] \mathrm{Cl} 3$ showed a molar conductivity of 83.5 $\mathrm{S} \mathrm{cm}^{2} \mathrm{~mol}^{-1}$, which falls in the range expected for $1: 2$ electrolytes. These results suggest that for $\left[\mathrm{Au}\left(\mathbf{L}^{\mathbf{1}}\right)_{2} \mathrm{Cl}_{2}\right] \mathrm{Cl} 2$ and $\left[\mathrm{AuL}^{3} \mathrm{Cl}_{2}\right] \mathrm{Cl} 4$ in DMSO solution, the complex cation is of the form the $\left[\mathrm{Au}(\mathrm{NHC})_{4} \mathrm{Cl}_{2}\right]^{+}$(the same as seen in the solid state), while for $\left[\mathrm{Au}\left(\mathbf{L}^{2}\right)_{2} \mathrm{Cl}_{2}\right] \mathrm{Cl} \mathrm{3}$, the complex cation is of the form $\left[\mathrm{Au}(\mathrm{NHC})_{4} \mathrm{Cl}\right]^{2+}$ in DMSO solution. Compared to $\left[\mathrm{Au}\left(\mathbf{L}^{\mathbf{1}}\right)_{2} \mathrm{Cl}_{2}\right]^{+}$ and $\left[\mathrm{AuL}^{3} \mathrm{Cl}_{2}\right]^{+}$, the higher propensity of $\left[\mathrm{Au}\left(\mathbf{L}^{2}\right)_{2} \mathrm{Cl}_{2}\right]^{+}$to undergo dissociation of $\mathrm{Cl}^{-}$may be consequence of increased steric congestion around the axial coordination sites, as suggested by the steeper inclination of the imidazolyl rings relative to the $\mathrm{AuC}_{4}$ plane in $\left[\mathrm{Au}\left(\mathbf{L}^{2}\right)_{2} \mathrm{Cl}_{2}\right]^{+}$(see above).

\section{NMR spectroscopy}

The ${ }^{1} \mathrm{H}$ and ${ }^{13} \mathrm{C}$ NMR spectra for $\mathrm{Au}^{\mathrm{III}}$ tetracarbene complexes (Fig. 5 and S1-S12 $\dagger$ ) are broadly consistent with the structures 
(a)

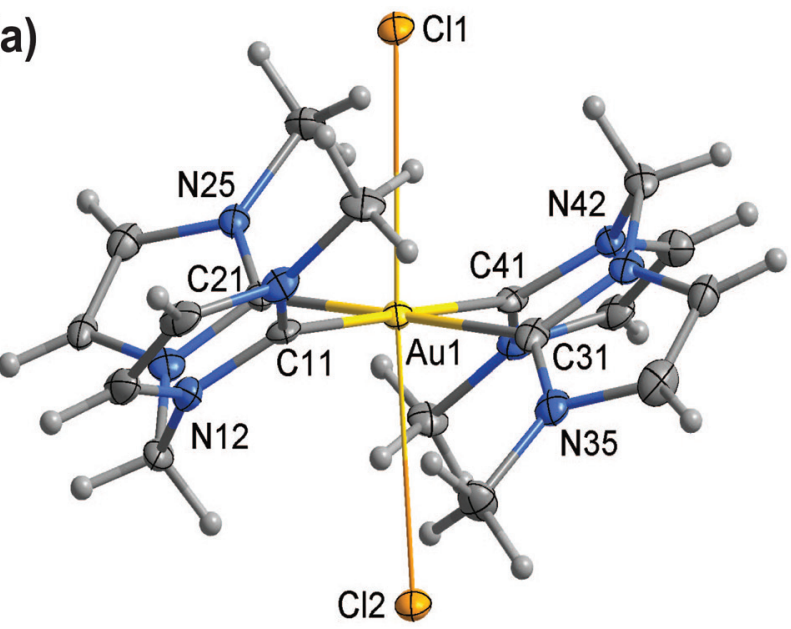

(b)

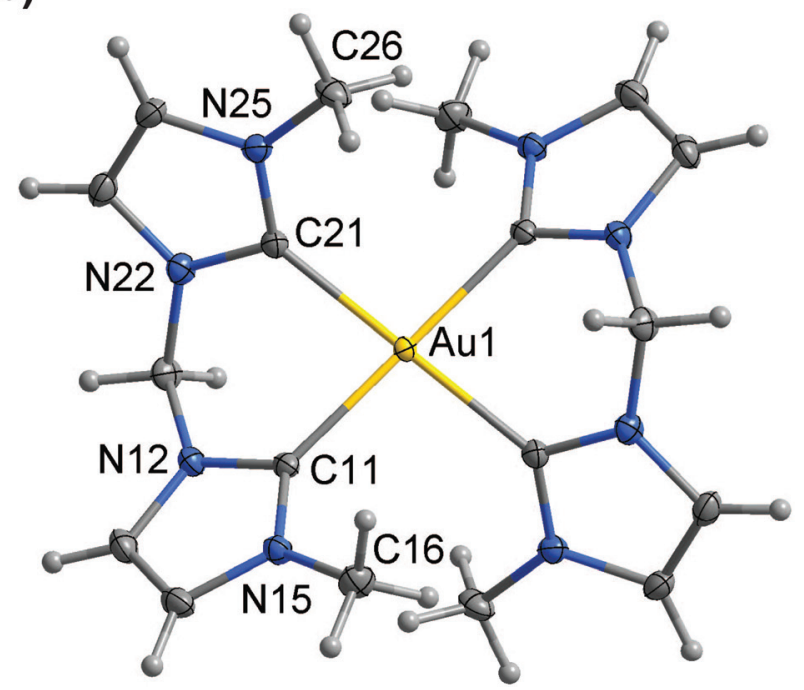

Fig. 1 (a) Crystal structure (50\% probability level for the displacement ellipsoids) of the cation of $\left[\mathrm{Au}\left(\mathrm{L}^{1}\right)_{2} \mathrm{Cl}_{2}\right] \mathrm{Cl}$ 2. Selected bond lengths ( $(\AA)$ and angles ( $\left.{ }^{\circ}\right)$ : $\mathrm{Au}(1)-\mathrm{C}(11)$ 2.040(9), $\mathrm{Au}(1)-\mathrm{C}(41)$ 2.043(9), $\mathrm{Au}(1)-\mathrm{C}(31)$ 2.046(9), $\mathrm{Au}(1)-\mathrm{C}(21)$ 2.050(9), $\mathrm{Au}(1)-\mathrm{Cl}(1)$ 3.148(2), $\mathrm{Au}(1)-\mathrm{Cl}(2)$ 3.192(2), $\mathrm{C}(11)-\mathrm{Au}(1)-\mathrm{C}(41)$ 179.3(3), C(41)-Au(1)-C(31) 85.0(4), Cl(1)-Au(1)-Cl(2) $176.78(6)$. (b) Crystal structure $(50 \%$ probability level for the displacement ellipsoids) of the cation of $\left[\mathrm{Au}\left(\mathrm{L}^{1}\right)_{2}\right]\left(\mathrm{PF}_{6}\right)_{3} 5 . \mathrm{PF}_{6}$ anions have been omitted for clarity. Selected bond lengths (Å) and angles $\left(^{\circ}\right)$ : $\mathrm{Au}(1)-\mathrm{C}(21)$ 2.041(2), Au(1)-C(11) 2.045(2), C(21)-Au(1)-C(11) 83.31(9).

seen in the solid state, but show affects of dissociation of chlorido in some cases.

The ${ }^{1} \mathrm{H}$ NMR spectrum of $\left[\mathrm{Au}\left(\mathbf{L}^{\mathbf{1}}\right)_{2} \mathrm{Cl}_{2}\right] \mathrm{Cl} 2$ in DMSO- $d_{6}$ solution shows a single signal due to the methyl protons (3.69 ppm), two doublet signals in the range 7.5-8.5 ppm, corresponding to the two non-equivalent protons of each imidazolyl ring, and a pair of doublets (AX pattern) centred at 8.09 and $6.79 \mathrm{ppm}$, corresponding to two non-equivalent protons in the methylene bridge linking the imidazolyl groups in each ligand. The non-equivalence of the methylene protons indicates that the "puckered" conformation adopted by the two $\mathbf{L}^{\mathbf{1}}$ (a)

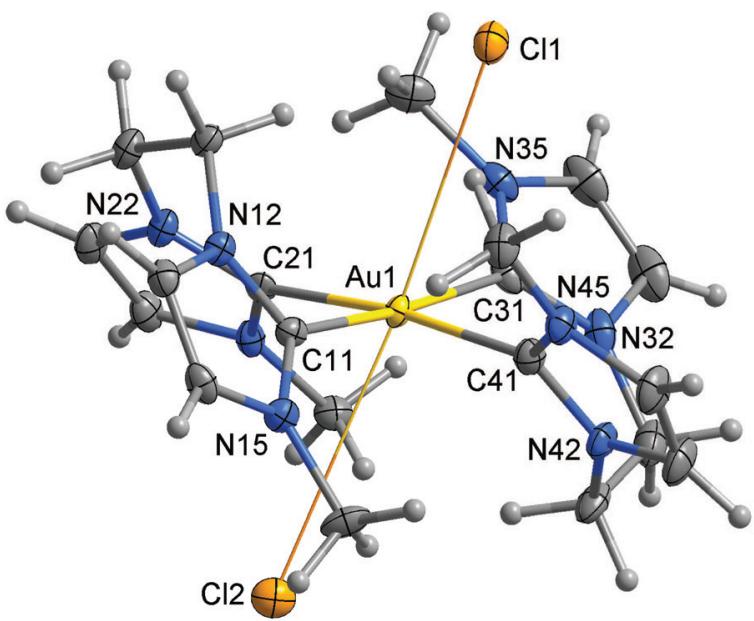

(b)

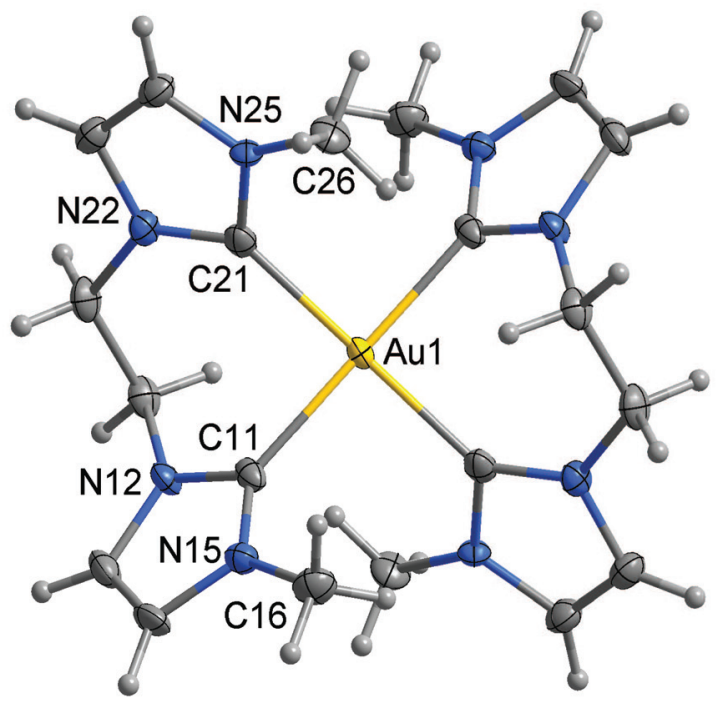

Fig. 2 (a) Crystal structure (50\% probability level for the displacement ellipsoids) of the cation of $\left[\mathrm{Au}\left(\mathrm{L}^{2}\right)_{2} \mathrm{Cl}_{2}\right] \mathrm{Cl} 3$. Selected bond lengths $(\AA)$ and angles $\left({ }^{\circ}\right)$ : $\mathrm{Au}(1)-\mathrm{C}(11)$ 2.024(4), $\mathrm{Au}(1)-\mathrm{C}(21)$ 2.054(4), $\mathrm{Au}(1)-\mathrm{Cl}(1)$ 3.433(1), $\mathrm{Au}(1)-\mathrm{Cl}(2) 3.693(1), \mathrm{C}(11)-\mathrm{Au}(1)-\mathrm{C}(31)$ 174.87(17), C(11)-Au(1)$\mathrm{C}(21)$ 89.84(17), $\mathrm{Cl}(1)-\mathrm{Au}(1)-\mathrm{Cl}(2)$ 172.17(3). (b) Crystal structure $(50 \%$ probability level for the displacement ellipsoids) of the cation of $\left[\mathrm{Au}\left(\mathrm{L}^{2}\right)_{2}\right]$ $\left(P F_{6}\right)_{3}$ 6. $P F_{6}$ anions have been omitted for clarity. Selected bond lengths (Å) and angles $\left({ }^{\circ}\right)$ : $A u(1)-C(11) 2.0402(18), A u(1)-C(21) 2.062(2), C(11)-$ $\mathrm{Au}(1)-\mathrm{C}(21)$ 88.22(8).

ligands in the complex in the solid state persists in solution and is rigid on the NMR timescale. The ${ }^{1} \mathrm{H}$ NMR spectrum of $\left[\mathrm{Au}\left(\mathbf{L}^{\mathbf{1}}\right)_{2}\right]\left(\mathrm{PF}_{6}\right)_{3} \mathbf{5}$ in DMSO- $d_{6}$ solution shows the same number of signals and splitting patterns, but the signals are at different chemical shifts, markedly so for the signals of the methylene protons. This observation is consistent with the change in coordination of $\mathrm{Au}^{\mathrm{III}}$ from $\mathrm{Au}(\mathrm{NHC})_{4} \mathrm{Cl}_{2}$ for $\left[\mathrm{Au}\left(\mathbf{L}^{\mathbf{1}}\right)_{2} \mathrm{Cl}_{2}\right] \mathrm{Cl} 2$ to $\mathrm{Au}(\mathrm{NHC})_{4}$ for $\left[\mathrm{Au}\left(\mathbf{L}^{\mathbf{1}}\right)_{2}\right]\left(\mathrm{PF}_{6}\right)_{3} \mathbf{5}$. We tentatively assign the doublet at $8.09 \mathrm{ppm}$ to the endo protons of the $\mathrm{CH}_{2}$ groups, and suggest that its markedly downfield chemical shift is a consequence of an intramolecular $\mathrm{H} \cdots \mathrm{Cl}$ hydrogen bonding interaction with a $\mathrm{Cl}$ ligand. Interestingly, 
(a)
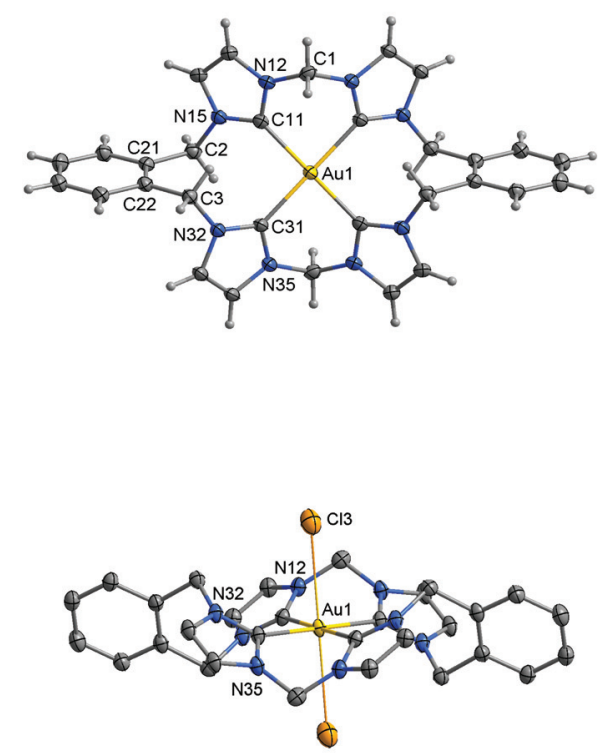

(b)
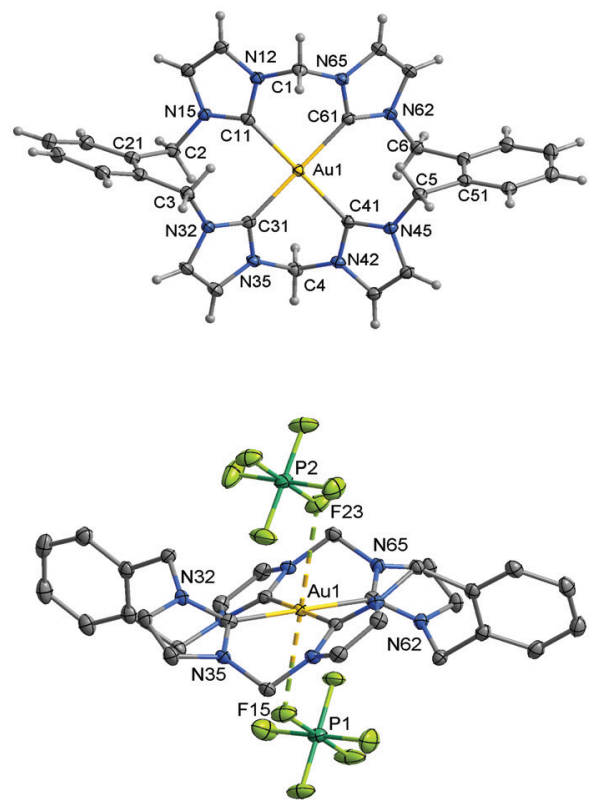

Fig. 3 (a) Crystal structure (30\% probability level for the displacement ellipsoids) of the cation of $\left[\mathrm{AuL}^{3} \mathrm{Cl}_{2}\right] \mathrm{Cl} 4$. Selected bond lengths ( $\left.\mathrm{A}\right)$ and angles ( ${ }^{\circ}$ : $\mathrm{Au}(1)-\mathrm{C}(11)$ 2.048(8), $\mathrm{Au}(1)-\mathrm{C}(31)$ 2.082(7), $\mathrm{Au}(1)-\mathrm{Cl}(3)$ 3.017(4), $\mathrm{C}(11)-\mathrm{Au}(1)-\mathrm{C}(31)$ 95.5(3). (b) Crystal structure (50\% probability level for the displacement ellipsoids) of the cation 1 of $\left[A u L^{3}\right]\left(P_{6}\right)_{3}$ 7. (Cation 2 is similar.) Selected bond lengths ( $(\AA)$ and angles $\left({ }^{\circ}\right)$ : $A u(1)-C(41) 2.051(2)$, $A u(1)-C(31)$ 2.052(2), $A u(1)-C(11)$ 2.056(2), $A u(1)-C(61)$ 2.056(2), $A u(2)-C(71) 2.050(2), A u(2)-C(91) 2.055(2), A u(1)-F(15) 3.004(5), A u(1)-F(23) 3.089(2)$, $A u(2)-F(33)$ 3.903(2), C(41)-Au(1)-C(31) 84.77(8), C(41)-Au(1)-C(11) 178.57(8), F(15)-Au(1)-F(23) 179.47(8), C(71)-Au(2)-C(91) 93.94(8).

in the solid state, the $\mathrm{Cl} \cdots \mathrm{H}$ distances for the endo hydrogens are 2.55 and $2.60 \AA$, which are within the range of $\sim 2.2 \AA$ A- 3.0 A seen for $\mathrm{C}-\mathrm{H}$... Cl hydrogen bonds. ${ }^{44}$

It is interesting to note that the ${ }^{1} \mathrm{H}$ NMR chemical shift of the signal for the endo $\mathrm{CH}_{2}$ protons of $\left[\mathrm{Au}\left(\mathbf{L}^{\mathbf{1}}\right)_{2} \mathrm{Cl}_{2}\right] \mathrm{Cl} 2$ in $\mathrm{D}_{2} \mathrm{O}$ solutions is close to that seen for $\left[\mathrm{Au}\left(\mathbf{L}^{\mathbf{1}}\right)_{2}\right]\left(\mathrm{PF}_{6}\right)_{3} \mathbf{5}$ in DMSO- $d_{6}$, and markedly different from that seen for $\left[\mathrm{Au}\left(\mathbf{L}^{\mathbf{1}}\right)_{2} \mathrm{Cl}_{2}\right] \mathrm{Cl} 2$ in DMSO- $d_{6}$. This observation suggests in $\mathrm{D}_{2} \mathrm{O}$ solution, the cation $\left[\mathrm{Au}\left(\mathbf{L}^{\mathbf{1}}\right)_{2} \mathrm{Cl}_{2}\right]^{+}$undergoes solvolysis to give $\left[\mathrm{Au}\left(\mathbf{L}^{\mathbf{1}}\right)_{2}\right]^{3+}$. Consistent with this suggestion, we found that when $\mathrm{NaCl}$ was dissolved in solutions prepared by dissolving $\left[\mathrm{Au}\left(\mathbf{L}^{\mathbf{1}}\right)_{2} \mathrm{Cl}_{2}\right] \mathrm{Cl} 2$ in $\mathrm{D}_{2} \mathrm{O}$, the signal for the endo $\mathrm{CH}_{2}$ protons shifted downfield (i.e., towards the chemical shift seen for the endo protons in $\left[\mathrm{Au}\left(\mathbf{L}^{\mathbf{1}}\right)_{2} \mathrm{Cl}_{2}\right]^{+}$), and moved back upfield (i.e., towards the chemical shift seen for the endo protons in $\left[\mathrm{Au}\left(\mathbf{L}^{\mathbf{1}}\right)_{2}\right]^{3+}$ ) when $\mathrm{Cl}^{-}$was precipitated from the sample as AgCl (Fig. S13 $\dagger$ ).

As noted above, conductance measurements showed that dissolution of $\left[\mathrm{Au}\left(\mathbf{L}^{2}\right)_{2} \mathrm{Cl}_{2}\right] \mathrm{Cl} 3$ in DMSO results in dissociation of one $\mathrm{Cl}^{-}$ligand from the Au centre and formation of $\left[\mathrm{Au}\left(\mathbf{L}^{2}\right)_{2} \mathrm{Cl}\right]^{2+}$ in solution. The ${ }^{1} \mathrm{H}$ NMR spectra of solutions prepared by dissolving $\left[\mathrm{Au}\left(\mathbf{L}^{2}\right)_{2} \mathrm{Cl}_{2}\right] \mathrm{Cl} 3$ in DMSO- $d_{6}$ can thus be considered to be spectra of the cation $\left[\mathrm{Au}\left(\mathbf{L}^{2}\right)_{2} \mathrm{Cl}\right]^{2+}$. These spectra again show a single signal (3.35 ppm) due to the methyl protons and two doublet signals (now in the range 7.7-7.9 ppm) corresponding to the two non-equivalent protons of each imidazole ring, with an apparent $\mathrm{AA}^{\prime} \mathrm{XX}^{\prime}$ pattern of signals centred at 4.91 and $5.46 \mathrm{ppm}$, corresponding to the protons in each ethylene bridge. These signals and splitting patterns suggest that the "puckered" conformation adopted by the two $\mathbf{L}^{2}$ ligands of $\left[\mathrm{Au}\left(\mathbf{L}^{2}\right)_{2} \mathrm{Cl}_{2}\right]^{+}$in the solid state persists in solution. In the solid state, there are four non-equivalent environments for the hydrogen atoms in each ethylene bridge, so the observation of an $\mathrm{AA}^{\prime} \mathrm{XX}^{\prime}$ pattern for the ethylene protons suggests that some twisting within each $\mathbf{L}^{2}$ ligand causes exo and endo protons on each carbon in an ethylene bridge to be rendered equivalent on the NMR timescale (Fig. 6).

There are small differences between the ${ }^{1} \mathrm{H}$ NMR signals seen for $\left[\mathrm{Au}\left(\mathbf{L}^{2}\right)_{2} \mathrm{Cl}\right]^{2+}$ and $\left[\mathrm{Au}\left(\mathbf{L}^{2}\right)_{2}\right]^{3+}$ (solutions prepared from $\left.\left[\mathrm{Au}\left(\mathbf{L}^{2}\right)_{2}\right]\left(\mathrm{PF}_{6}\right)_{3}\right) 6$ in terms chemical shift, but the number of signals and splitting patterns are the same in each case. For $\left[\mathrm{Au}\left(\mathbf{L}^{2}\right)_{2} \mathrm{Cl}\right]^{2+}$, we note that the existence of an $\mathrm{Au}(\mathrm{NHC})_{4} \mathrm{Cl}$ coordination motif (approximately square pyramidal) must render the two $\mathbf{L}^{2}$ ligands inequivalent if the ligands are puckered in the same way as seen in the solid state for $\left[\mathrm{Au}\left(\mathbf{L}^{2}\right)_{2} \mathrm{Cl}_{2}\right]$ Cl 3. Since the number of NMR signals is consistent with the $\mathbf{L}^{2}$ ligands being equivalent on the NMR timescale, it may be that the two $\mathbf{L}^{2}$ ligands are rendered equivalent on the NMR timescale by rapid dissociation and re-association of the chlorido ligand (Fig. 5(b)).

The ${ }^{1} \mathrm{H}$ NMR spectra for both $\left[\mathrm{AuL}^{3} \mathrm{Cl}_{2}\right] \mathrm{Cl} \mathbf{4}$ and $\left[\mathrm{AuL}^{3}\right]$ $\left(\mathrm{PF}_{6}\right)_{3} 7$ in DMSO- $d_{6}$ solution are analogous to those seen for $\left[\mathrm{Au}\left(\mathbf{L}^{\mathbf{1}}\right)_{2} \mathrm{Cl}_{2}\right] \mathrm{Cl} 2$ and $\left[\mathrm{Au}\left(\mathbf{L}^{\mathbf{1}}\right)_{2}\right]\left(\mathrm{PF}_{6}\right)_{3}$ 5. Major differences between the two samples in terms of in chemical shifts of the 

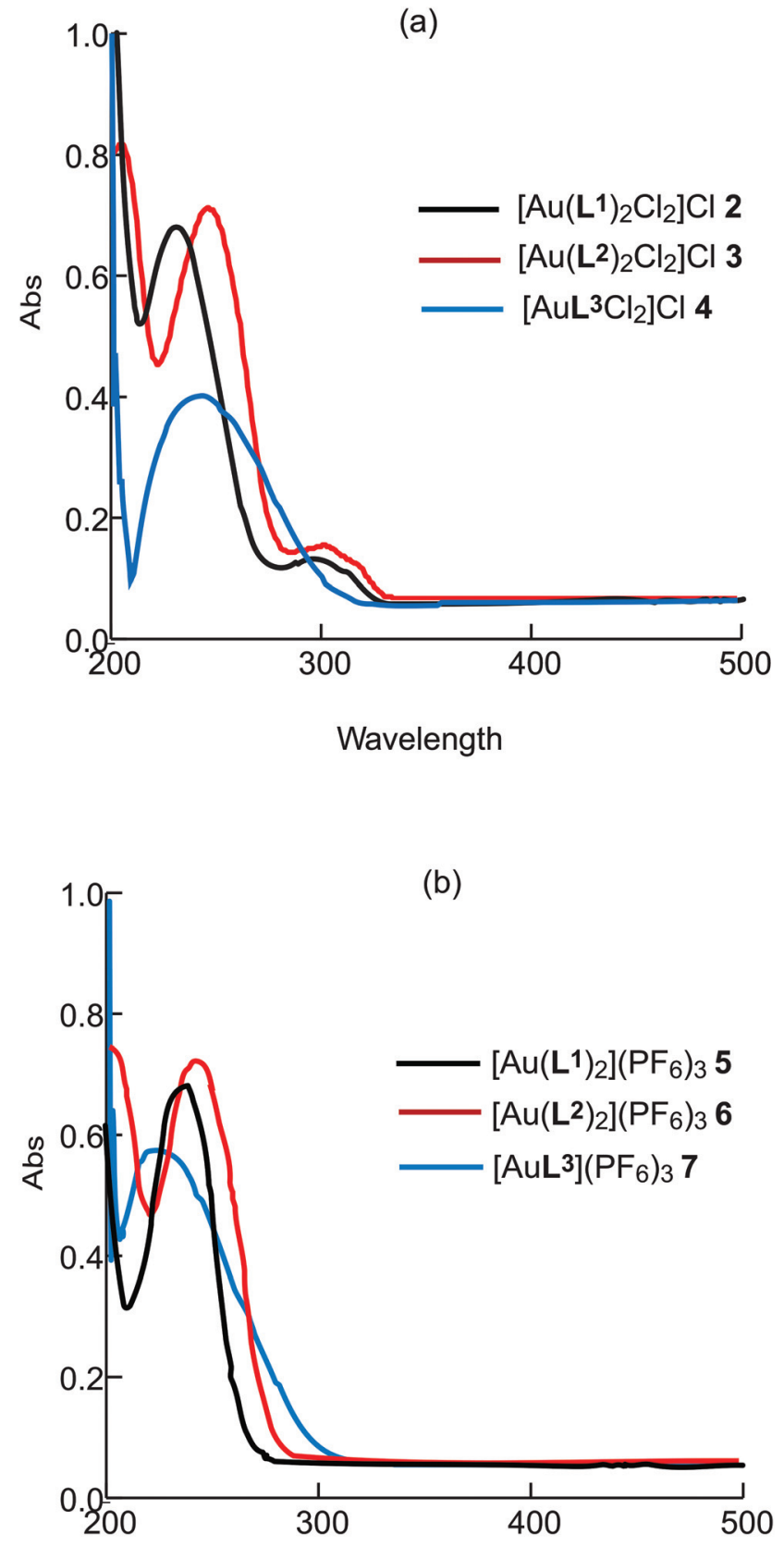

Wavelength

Fig. 4 UV-vis absorption spectra of (a) $\left[\mathrm{Au}\left(\mathrm{L}^{1}\right)_{2} \mathrm{Cl}_{2}\right] \mathrm{Cl}$ 2, $\left[\mathrm{Au}\left(\mathrm{L}^{2}\right)_{2} \mathrm{Cl}_{2}\right] \mathrm{Cl}$ 3, $\left[\mathrm{AuL}{ }^{3} \mathrm{Cl}_{2}\right] \mathrm{Cl} 4$ and (b) $\left[\mathrm{Au}\left(\mathrm{L}^{1}\right)_{2}\right]\left(\mathrm{PF}_{6}\right)_{3} 5,\left[\mathrm{Au}\left(\mathrm{L}^{2}\right)_{2}\right]\left(\mathrm{PF}_{6}\right)_{3} 6,\left[\mathrm{AuL}^{3}\right]\left(\mathrm{PF}_{6}\right)_{3} 7$ in $\mathrm{MeCN}$.

protons of the methylene linkers, and to a lesser extent those of the benzylic protons, are consistent with a change in coordination of $\mathrm{Au}^{\text {III }}$, from $\mathrm{Au}(\mathrm{NHC})_{4} \mathrm{Cl}_{2}$ in $\left[\mathrm{AuL}^{3} \mathrm{Cl}_{2}\right] \mathrm{Cl} 4$ to $\mathrm{Au}(\mathrm{NHC})_{4}$ (or a solvated form) in $\left[\mathrm{AuL}^{3}\right]\left(\mathrm{PF}_{6}\right)_{3}$ 7. The number of signals and splitting patterns are consistent with the ligand $\mathbf{L}^{3}$ adopting a "puckered" conformation that does not invert on the NMR timescale.

In the ${ }^{13} \mathrm{C}$ NMR spectra of the new $\mathrm{Au}^{\mathrm{III}}-\mathrm{NHC}$ complexes having an $\mathrm{Au}(\mathrm{NHC})_{4}$ motif, the signal for the carbene carbon
Table 3 UV-vis spectroscopic data and conductivity properties of $\mathrm{Au}^{\mathrm{III}}-\mathrm{NHC}$ complexes

\begin{tabular}{llr}
\hline Complex & $\lambda_{\text {max }} / \mathrm{nm}\left(\varepsilon / \mathrm{M}^{-1} \mathrm{~cm}^{-1}\right)^{a}$ & $\Lambda_{\mathrm{M}}{ }^{b}\left(\mathrm{~S} \mathrm{~cm}^{2} \mathrm{~mol}^{-1}\right)$ \\
\hline$\left[\mathrm{Au}\left(\mathbf{L}^{\mathbf{1}}\right)_{2} \mathrm{Cl}_{2}\right] \mathrm{Cl} \mathbf{2}$ & $302(3600), 235(14100)$ & 41.6 \\
{$\left[\mathrm{Au}\left(\mathbf{L}^{1}\right)_{2}\right]\left(\mathrm{PF}_{6}\right)_{3} \mathbf{5}$} & $250(14600)$ & 114.6 \\
{$\left[\mathrm{Au}\left(\mathbf{L}^{2}\right)_{2} \mathrm{Cl}_{2}\right] \mathrm{Cl} \mathbf{3}$} & $301(4100), 245(15200)$ & 83.5 \\
{$\left[\mathrm{Au}\left(\mathbf{L}^{2}\right)_{2}\right]\left(\mathrm{PF}_{6}\right)_{3} \mathbf{6}$} & $241(15000)$ & 118.7 \\
{$\left[\mathrm{Au} \mathbf{L}^{3} \mathrm{Cl}_{2}\right] \mathrm{Cl} \mathrm{l}_{\mathbf{4}}$} & $275(8400)$ & 41.8 \\
{$\left[\mathrm{AuL} \mathbf{L}^{3}\right]\left(\mathrm{PF}_{6}\right)_{3} 7$} & $256(11600)$ & 113.4
\end{tabular}

${ }^{a}$ Measured in $0.05 \mathrm{mM}$ MeCN solution at $298 \mathrm{~K} .{ }^{b}$ Measured in $1 \mathrm{mM}$ DMSO solution at $298 \mathrm{~K}$.

occurs near $146 \mathrm{ppm}$, which is close to that reported for the related $\left[\mathrm{Au}(\mathrm{NHC})_{4}\right]^{+}$complex $\mathbf{1}^{32}$ but approximately $35 \mathrm{ppm}$ upfield of that for the carbene carbons in $\mathrm{Au}^{\mathrm{I}}-\mathrm{NHC}$ complexes. ${ }^{8}$ For comparison, imidazolium-derived $\mathrm{Au}^{\mathrm{III}}$ complexes of form $\left[\mathrm{Au}\left(\mathrm{R}_{2} \mathrm{Im}\right) \mathrm{Cl}_{3}\right]$ ( $\mathrm{R}_{2} \mathrm{Im}=$ 1,3-dialkylimidazol-2-ylidene) show a carbene signal in the range $134-141 \mathrm{ppm},{ }^{14,45}$ and $\left[\mathrm{Au}\left(\mathrm{R}_{2} \mathrm{Im}\right)_{2} \mathrm{Cl}_{2}\right]^{+}$and $\left[\mathrm{Au}_{2}\left(\mathbf{L}^{1}\right)_{2} \mathrm{Cl}_{4}\right]^{2+}$ exhibit carbene signals near 150-155 ppm, ${ }^{46,47}$ while $\left[\mathrm{Au}\left(\mathrm{R}_{2} \mathrm{Bim}\right) \mathrm{Cl}_{3}\right]$ and $\left[\mathrm{Au}\left(\mathrm{R}_{2} \mathrm{Bim}\right)_{2} \mathrm{Cl}_{2}\right]^{+}\left(\mathrm{R}_{2} \mathrm{Bim}=1,3\right.$-dialkylbenzimidazol-2-ylidene $)$ exhibit carbene signals ${ }^{35}$ about 10 ppm downfield of those of their imidazolium-derived counterparts.

\section{H-D exchange reactions}

Imidazolium ions are well-known to undergo H/D exchange reactions. ${ }^{48-50}$ We have explored H/D exchange reactions for the imidazolium salt $\mathbf{L}^{\mathbf{1}} \cdot 2 \mathrm{HCl}$ and the $\mathrm{Au}^{\mathrm{III}}$ complex $\left[\mathrm{Au}\left(\mathbf{L}^{\mathbf{1}}\right)_{2}\right]^{3+}$ (formed from $\left[\mathrm{Au}\left(\mathbf{L}^{\mathbf{1}}\right)_{2} \mathrm{Cl}_{2}\right] \mathrm{Cl}$ 2, see above) in $\mathrm{D}_{2} \mathrm{O}$ solutions (Fig. 7). For $\mathbf{L}^{1} \cdot 2 \mathrm{HCl}$, the imidazolium $\mathrm{H} 2$ protons exchange quickly ( $<5 \mathrm{~min}$ at room temperature) with deuterium from the solvent. This finding is consistent with previous observations that the ${ }^{1} \mathrm{H}$ NMR signal for the $\mathrm{H} 2$ protons of imidazolium salts generally "underintegrates" in spectra recorded in $\mathrm{D}_{2} \mathrm{O}$ and methanol- $d_{4}$ solutions at room temperature. ${ }^{51-53}$ When the sample was heated at $100{ }^{\circ} \mathrm{C}$, the imidazolyl $\mathrm{H} 4 / \mathrm{H} 5$ protons were fully exchanged over the course of about $48 \mathrm{~h}$, while the $\mathrm{CH}_{2}$ protons were about $40 \%$ exchanged over the same period, and the $\mathrm{CH}_{3}$ protons underwent little or no exchange. The analogous exchange reactions were markedly faster for $\left[\operatorname{Au}\left(\mathbf{L}^{1}\right)_{2}\right]^{3+}$ under similar conditions: the imidazolyl H4/H5 protons $(\delta 7.91,7.61 \mathrm{ppm})$ were fully exchanged within $17 \mathrm{~h}$ at $100{ }^{\circ} \mathrm{C}$, as indicated by disappearance of the $\mathrm{H} 4 / \mathrm{H} 5$ signals from the ${ }^{1} \mathrm{H}$ NMR spectrum, and the $\mathrm{CH}_{2}$ protons were fully exchanged within $48 \mathrm{~h}$ at $100{ }^{\circ} \mathrm{C}$ (Fig. $7 \mathrm{~b}$ ). Experiments conducted using $t$-butanol as an internal standard showed negligible $\mathrm{H} / \mathrm{D}$ exchange of $\mathrm{CH}_{3}$ protons in $\left[\mathrm{Au}\left(\mathbf{L}^{\mathbf{1}}\right)_{2}\right]^{3+}$ even after heating for $48 \mathrm{~h}$ (Fig. S14†). Not surprisingly, the H/D exchange reactions of $\left[\mathrm{Au}\left(\mathbf{L}^{1}\right)_{2}\right]^{3+}$ were catalysed by base-in the presence of two equivalents of $\mathrm{K}_{2} \mathrm{CO}_{3}$, the imidazolyl $\mathrm{H} 4 / \mathrm{H} 5$ protons (but not the $\mathrm{CH}_{2}$ protons) underwent partial exchange over $48 \mathrm{~h}$ at room temperature (Fig. S15 $\dagger$ ), and in the presence of two equivalents of $\mathrm{NaOH}$, both the imidazolyl $\mathrm{H} 4 / \mathrm{H} 5$ protons and the $\mathrm{CH}_{2}$ protons were almost completely exchanged overnight at room temperature (Fig. S16 $\dagger$ ). The 

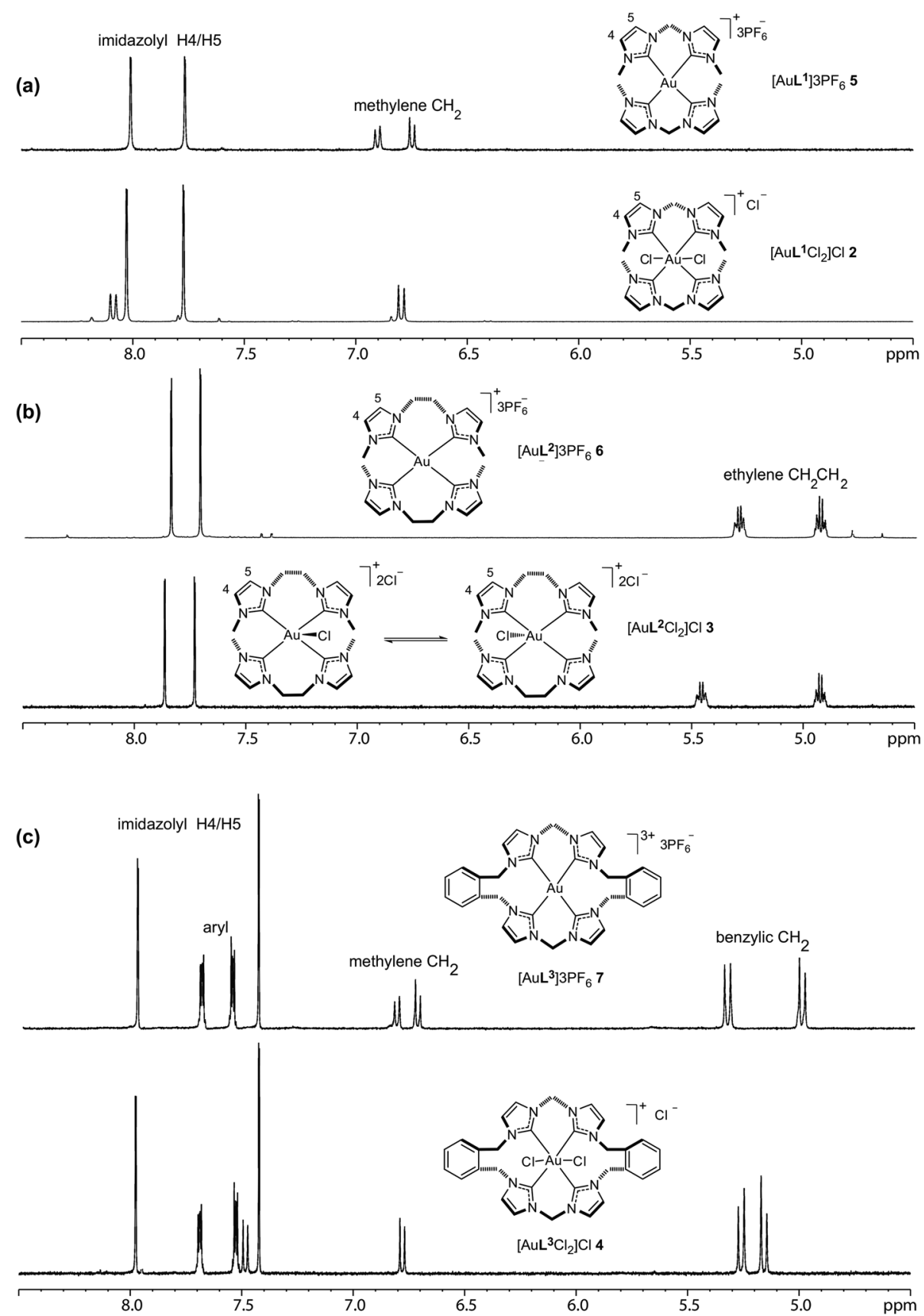

Fig. $5{ }^{1} \mathrm{H}$ NMR spectra $\left(600 \mathrm{MHz}\right.$, DMSO- $\left.d_{6}\right)$ for: (a) $\left[\mathrm{Au}\left(\mathrm{L}^{1}\right)_{2} \mathrm{Cl}_{2}\right] \mathrm{Cl}$ 2, $\left[\mathrm{Au}\left(\mathrm{L}^{1}\right)_{2}\right]\left(\mathrm{PF}_{6}\right)_{3}$ 5; (b) $\left[\mathrm{Au}\left(\mathrm{L}^{2}\right)_{2} \mathrm{Cl}\right] \mathrm{Cl}_{2} 3,\left[\mathrm{Au}\left(\mathrm{L}^{2}\right)_{2}\right]\left(\mathrm{PF}_{6}\right)_{3}$ 6; and $(\mathrm{c})\left[\mathrm{AuL} \mathrm{L}^{3} \mathrm{Cl}{ }_{2}\right] \mathrm{Cl} 4$, $\left[\mathrm{AuL}^{3}\right]\left(\mathrm{PF}_{6}\right)_{3} 7$.

high charge on the $\left[\mathrm{Au}\left(\mathbf{L}^{\mathbf{1}}\right)_{2}\right]^{3+}$ cation is likely a factor contributing to the fast $\mathrm{H} / \mathrm{D}$ exchange seen in $\mathrm{D}_{2} \mathrm{O}$ (formation of a deprotonated intermediate $\left[\mathrm{Au}\left(\mathbf{L}^{\mathbf{1}}\right)_{2}-\mathrm{H}\right]^{2+}$ would be favoured by the concomitant decrease in concentration of positive charge on the complex).

\section{Stability studies}

The new $\mathrm{Au}^{\mathrm{III}}(\mathrm{NHC})_{4}$ complexes reported in this work were stable in the solid state at room temperature under air for at least 1 year. The $\mathrm{D}_{2} \mathrm{O}$ exchange experiment described above suggests surprisingly high stability for the $\mathrm{Au}^{\mathrm{III}}(\mathrm{NHC})_{4}$ complexes, in that they can survive extended periods in solution at $100{ }^{\circ} \mathrm{C}$, albeit with $\mathrm{H} / \mathrm{D}$ exchange occurring. To further explore the stability of the new $\mathrm{Au}^{\mathrm{III}}(\mathrm{NHC})_{4}$ complexes, we have used ${ }^{1} \mathrm{H}$ NMR spectroscopy to assessed the longevity of various samples in DMSO- $d_{6}$ solutions at elevated temperatures. After a DMSO- $d_{6}$ solution containing $\left[\mathrm{Au}\left(\mathbf{L}^{\mathbf{1}}\right)_{2}\right]\left(\mathrm{PF}_{6}\right)_{3} \mathbf{5}$ was stored at room temperature for 6 months and then heated at $120^{\circ} \mathrm{C}$ for $26 \mathrm{~h}$, there was no significant change to the ${ }^{1} \mathrm{H}$ NMR spectrum (Fig. S17 $\dagger$ ). The same applied for a DMSO- $d_{6}$ solution contain- 

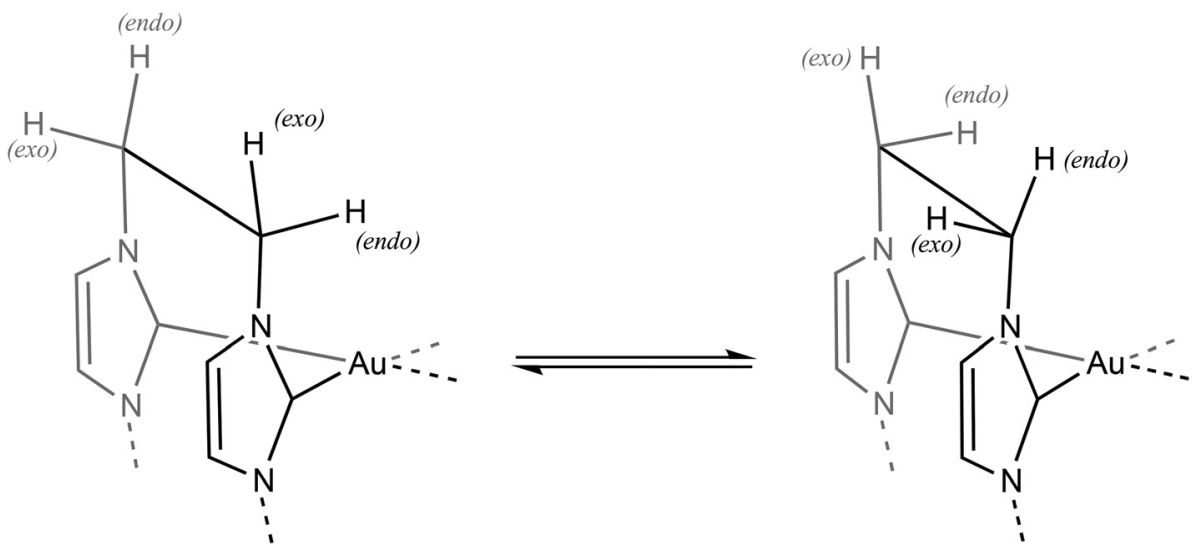

Fig. 6 Proposed twisting of the ethylene bridge to account for symmetry observed for ${ }^{1} \mathrm{H}$ NMR signals of $\left[\mathrm{Au}\left(\mathrm{L}^{2}\right)_{2} \mathrm{Cl}_{2}\right] \mathrm{Cl} 3$ in $\mathrm{DMSO}-d_{6}$ solution.

(a)
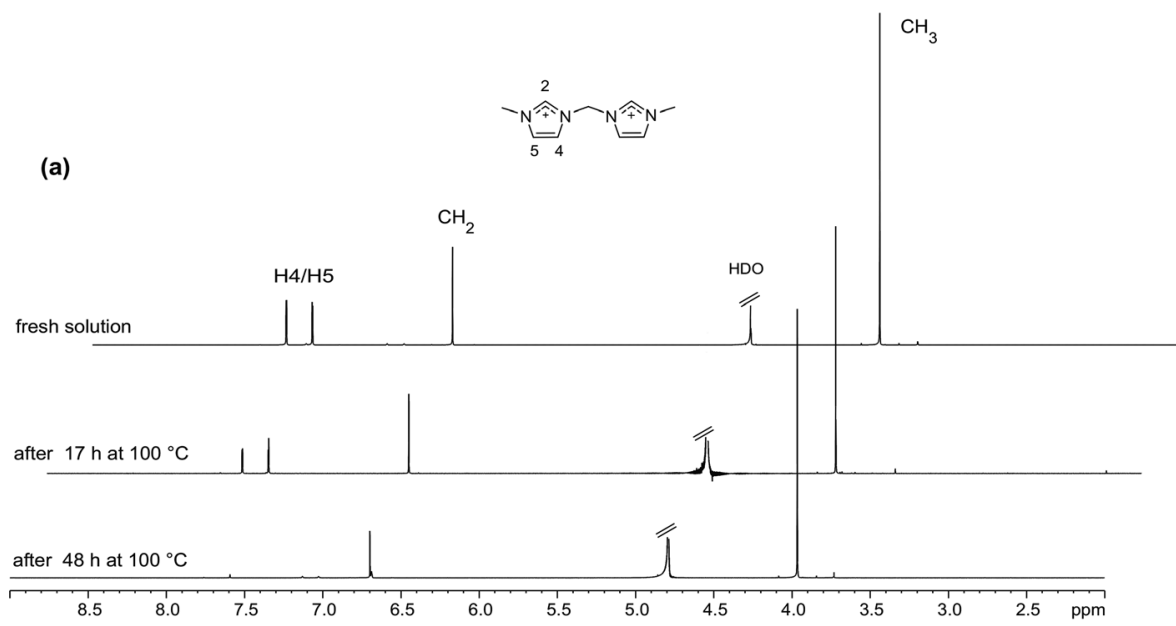

(b)
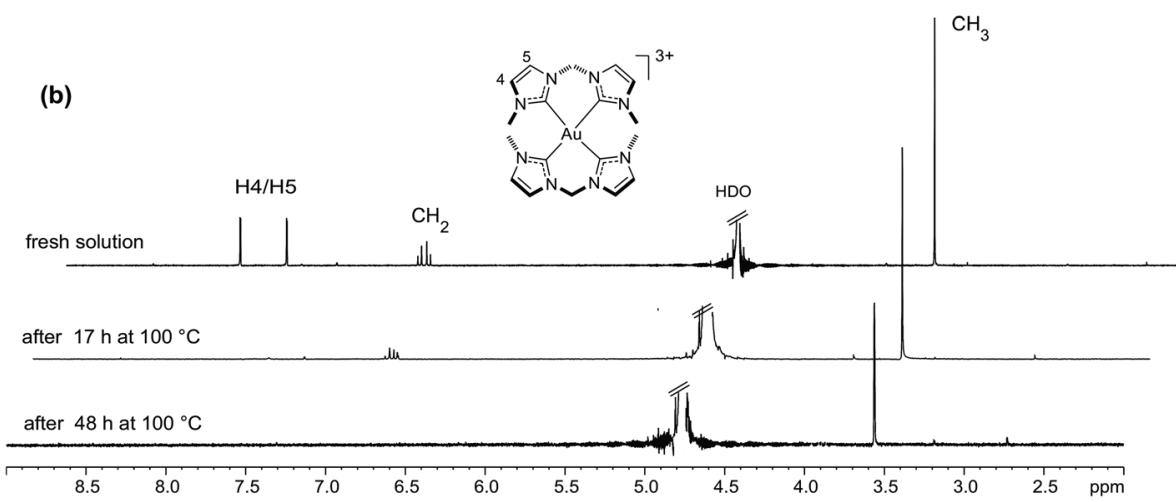

Fig. $7{ }^{1} \mathrm{H}$ NMR spectra $\left(600.13 \mathrm{MHz}, \mathrm{D}_{2} \mathrm{O}\right)$ for solutions of (a) the imidazolium salt $\mathrm{L}^{1} \cdot 2 \mathrm{HCl}$ and $(\mathrm{b})$ the $\mathrm{Au}{ }^{\prime \prime \prime}$ complex $\left[\mathrm{Au}\left(\mathrm{L}^{1}\right)_{2}\right]^{3+}(\mathrm{prepared} \mathrm{from}$ $\left.\left[\mathrm{Au}\left(\mathrm{L}^{1}\right)_{2} \mathrm{Cl}_{2}\right] \mathrm{Cl}\right) 2$, showing disappearance of signals due to $\mathrm{H} / \mathrm{D}$ exchange reactions. For $\mathrm{L}^{1} \cdot 2 \mathrm{HCl}$, no signal for the $\mathrm{H} 2$ protons was detected even from freshly-prepared solutions.

ing $\left[\mathrm{Au}\left(\mathbf{L}^{3}\right)\right]\left(\mathrm{PF}_{6}\right)_{3} 7$ that was maintained at $120{ }^{\circ} \mathrm{C}$ for 7 days (Fig. S19†). The chlorido complex $\left[\mathrm{Au}\left(\mathbf{L}^{2}\right)_{2} \mathrm{Cl}_{2}\right] \mathrm{Cl} 3$ was somewhat less stable; after a DMSO- $d_{6}$ solution containing this compound was heated at $120^{\circ} \mathrm{C}$ for 7 days, integration of the imidazolyl $\mathrm{H} 4 / \mathrm{H} 5$ region of the ${ }^{1} \mathrm{H}$ NMR spectrum indicating that $c a .20 \%$ of the initial $\mathrm{Au}^{\mathrm{III}}$ complex $\left[\mathrm{Au}\left(\mathbf{L}^{2}\right)_{2} \mathrm{Cl}_{2}\right]^{+}$had decomposed, the major decomposition product being the known ${ }^{54}$ dinuclear $\mathrm{Au}^{\mathrm{I}}$ complex $\left[\mathrm{Au}_{2}\left(\mathbf{L}^{2}\right)_{2}\right]^{2+}$ (Fig. S18 $\dagger$ ). The slightly lower stability of $\left[\mathrm{Au}\left(\mathbf{L}^{2}\right)_{2} \mathrm{Cl}_{2}\right]^{+}$may be a consequence of slightly higher strain in the chelate rings (e.g., in the ethylene link joining the NHC units in $\left[\mathrm{Au}\left(\mathbf{L}^{2}\right)_{2} \mathrm{Cl}_{2}\right]^{+}, \mathrm{N}-\mathrm{C}-\mathrm{C}$ angles are 113.4(3), 113.8(4), 115.7(4) and 116.4(4) ${ }^{\circ}$; in the methylene 
linker in $\left[\mathrm{Au}\left(\mathbf{L}^{\mathbf{1}}\right)_{2} \mathrm{Cl}_{2}\right]^{+}, \quad \mathrm{N}-\mathrm{C}-\mathrm{N}$ angles are $108.5(7)$ and 109.1 $(7)^{\circ}$, closer to the ideal tetrahedral angle, $\left.109.5^{\circ}\right)$. For comparison, salts of the dinuclear $\mathrm{Au}^{\mathrm{III}}$ complex $\left[\mathrm{Au}_{2}\left(\mathbf{L}^{\mathbf{1}}\right)_{2} \mathrm{Cl}_{4}\right]^{2+}$ and its bromido counterpart, ${ }^{8,47}$ which contain $\mathrm{Au}^{\mathrm{III}}(\mathrm{NHC})_{2} \mathrm{X}_{2}$ moieties rather than $\mathrm{Au}^{\mathrm{III}}(\mathrm{NHC})_{4}$ moieties, were far less stable. At room temperature in the solid state, $c a .50 \%$ of the $\mathrm{Au}^{\mathrm{III}} / \mathrm{Au}^{\mathrm{III}}$ complex $\left[\mathrm{Au}_{2}\left(\mathbf{L}^{1}\right)_{2} \mathrm{Br}_{4}\right]^{2+}$ had decomposed to the $\mathrm{Au}^{\mathrm{I}} / \mathrm{Au}^{\mathrm{III}}$ complex $\left[\mathrm{Au}_{2}\left(\mathbf{L}^{1}\right)_{2} \mathrm{Br}_{2}\right]^{2+}$ over 6 months (Fig. S20 and $\mathrm{S} 21 \dagger)$, and no $\mathrm{Au}^{\mathrm{III}}$ species could be detected after a DMSO- $d_{6}$ solution containing $\left[\mathrm{Au}_{2}\left(\mathbf{L}^{1}\right)_{2} \mathrm{Br}_{4}\right]^{2+}$ and $\left[\mathrm{Au}_{2}\left(\mathbf{L}^{1}\right)_{2} \mathrm{Br}_{2}\right]^{2+}$ was heated at $120{ }^{\circ} \mathrm{C}$ for $2 \mathrm{~h}$ (Fig. S21†). Similar results were seen for solutions containing $\left[\mathrm{Au}_{2}\left(\mathbf{L}^{1}\right)_{2} \mathrm{Cl}_{4}\right]^{2+}$ (Fig. S22†) and $\left[\mathrm{Au}_{2}\left(\mathbf{L}^{2}\right)_{2} \mathrm{Br}_{4}\right]^{2+}$ (Fig. S23†े).

The high stability of $\mathrm{Au}^{\mathrm{III}}(\mathrm{NHC})_{4}$ complexes compared to their $\mathrm{Au}^{\mathrm{III}}(\mathrm{NHC})_{2}(\text { halide })_{2}$ counterparts may reflect the strong $\sigma$-donating ability of the NHC ligand, which is better able to stabilise the $\mathrm{Au}^{\mathrm{III}}$ centre than the weaker $\sigma$-donating halide ligands. The robustness of the metal-NHC bond and steric protection exerted by the chelating NHC ligands must also contribute to the enhanced stability of the $\mathrm{Au}^{\mathrm{III}}(\mathrm{NHC})_{4}$ complexes compared to their $\mathrm{Au}^{\mathrm{III}}(\mathrm{NHC})_{2} \mathrm{X}_{2}$ counterparts.

Cyclovoltammetric studies showed that the $\mathrm{Au}^{\mathrm{III}}$ complexes did not undergo reversible redox reactions at room temperature in acetonitrile with $\mathrm{Bu}_{4} \mathrm{NClO}_{4}$ as electrolyte (see ESI†).

\section{Conclusion}

Three new $\mathrm{Au}^{\mathrm{III}}$ complexes of form $\left[\mathrm{Au}(\mathrm{NHC})_{4} \mathrm{Cl}_{2}\right] \mathrm{Cl}$ may be synthesized in good yield directly from bis- and tetrakis(imidazolium) salts and $\mathrm{KAuCl}_{4}$ in the presence of base. These formally 20 electron complexes have tetragonally distorted octahedral coordination of the $\mathrm{Au}^{\text {III }}$ centre, the NHC groups making an approximately square planar array and the chlorido ligands occupying more distant axial positions. The $\mathrm{Au}^{\mathrm{III}}(\mathrm{NHC})_{4}$ motif is remarkably stable, resisting decomposition in DMSO solution at $120{ }^{\circ} \mathrm{C}$ or $\mathrm{D}_{2} \mathrm{O}$ at $100{ }^{\circ} \mathrm{C}$ for extended periods. The axial (chlorido) ligands are labile, and metathesis of the $\left[\mathrm{Au}(\mathrm{NHC})_{4} \mathrm{Cl}_{2}\right] \mathrm{Cl}$ salts with $\mathrm{KPF}_{6}$ in methanol/water results in removal of the chlorido ligands and formation of three new, formally 16 electron complexes of form $\left[\mathrm{Au}(\mathrm{NHC})_{4}\right]\left(\mathrm{PF}_{6}\right)_{3}$. The $\left[\mathrm{Au}(\mathrm{NHC})_{4}\right]^{3+}$ ion is sufficiently stable to undergo base-catalysed $\mathrm{H} / \mathrm{D}$ exchange reactions at most sites on the NHC ligands in $\mathrm{D}_{2} \mathrm{O}$ at $100{ }^{\circ} \mathrm{C}$ without evidence of decomposition.

\section{Experimental section}

\section{General procedures}

Nuclear magnetic resonance spectra were recorded using Bruker ARX400 (400.13 MHz for $\left.{ }^{1} \mathrm{H}\right)$, Bruker ARX500 (500.13 MHz for ${ }^{1} \mathrm{H}$ and $125.77 \mathrm{MHz}$ for ${ }^{13} \mathrm{C}$ ), or Bruker ARX $600\left(600.13 \mathrm{MHz}\right.$ for ${ }^{1} \mathrm{H}, 150.90 \mathrm{MHz}$ for $\left.{ }^{13} \mathrm{C}\right)$ spectrometers at ambient temperature. ${ }^{1} \mathrm{H}$ and ${ }^{13} \mathrm{C}$ NMR chemical shifts were referenced to signals of the solvent (DMSO- $d_{6}:{ }^{1} \mathrm{H} 2.50 \mathrm{ppm}$;
${ }^{13} \mathrm{C}$ 39.52). When necessary, assignments were made with the aid of ${ }^{1} \mathrm{H}^{13}{ }^{13} \mathrm{C}$ HSQC (heteronuclear single quantum coherence) and ${ }^{1} \mathrm{H}_{-}{ }^{13} \mathrm{C}$ HMBC (heteronuclear multiple bond correlation) spectra. Conductance measurements were performed by using a TPS Aqua-CP/A conductivity meter. Cyclic voltammetry experiments were recorded using an eDAQ e-corder 401 system in a three-electrode cell with a glassy carbon ( $1 \mathrm{~mm}$ diameter) working electrode, a platinum (1 $\mathrm{mm}$ diameter) counter electrode, and a platinum wire reference electrode. Measurements were taken at room temperature $\left(25{ }^{\circ} \mathrm{C}\right)$ in acetonitrile with $0.1 \mathrm{M} \mathrm{Bu}_{4} \mathrm{NClO}_{4}$ as a supporting electrolyte. Microanalyses were performed by The School of Chemistry \& Molecular Bioscience, University of Queensland, Australia, and the Instrument Center of National Chung Hsing University, Taiwan. High resolution mass spectra were measured using Agilent LCMS 6510 Q-TOF and Waters LCT Premier XE spectrometers, using the ESI method, with $\mathrm{MeCN}: \mathrm{H}_{2} \mathrm{O}(9: 1)$ as solvent. All organometallic compounds were prepared under a nitrogen atmosphere. The imidazolium salts $\mathbf{L}^{\mathbf{1}} \cdot 2 \mathrm{HCl}$, $\mathbf{L}^{2} \cdot 2 \mathrm{HCl},{ }^{55,56}$ and $\mathbf{L}^{3} \cdot 4 \mathrm{HCl}^{57}$ were prepared according to literature procedures, and the $\mathrm{Au}^{\mathrm{III}}$ complexes $\left[\mathrm{Au}_{2}\left(\mathbf{L}^{1}\right)_{2} \mathrm{X}_{4}\right] \mathrm{X}_{2}(\mathrm{X}=$ $\mathrm{Cl}, \mathrm{Br})$ and $\left[\mathrm{Au}_{2}\left(\mathrm{~L}^{2}\right)_{2} \mathrm{Br}_{4}\right] \mathrm{Br}_{2}$ were prepared in the same way as the corresponding hexafluorophosphate salts. ${ }^{8,47}$

\section{Synthesis of $\mathrm{Au}^{\text {III- }}$-NHC complexes}

Complex 2, $\left[\mathbf{A u}\left(\mathbf{L}^{1}\right)_{2} \mathbf{C l}_{2}\right]$ Cl. A solution of LiOAc $(80 \mathrm{mg}$, $1.21 \mathrm{mmol})$ in DMF (5 mL) was added to a solution of the bis (imidazolium) salt $\mathbf{L}^{\mathbf{1}} \cdot 2 \mathrm{HCl}\left(99 \mathrm{mg}, 0.40 \mathrm{mmol}\right.$ ) and $\mathrm{KAuCl}_{4}$ $(75 \mathrm{mg}, 0.20 \mathrm{mmol})$ in DMF $(10 \mathrm{~mL})$ at $80^{\circ} \mathrm{C}$. The mixture was then heated to $100{ }^{\circ} \mathrm{C}$ and maintained at that temperature for $5 \mathrm{~h}$. During this time a white precipitate formed. The precipitate was collected by filtration and washed successively with DMF, acetone, and $\mathrm{Et}_{2} \mathrm{O}$ to give $\left[\mathrm{Au}\left(\mathbf{L}^{1}\right)_{2} \mathrm{Cl}_{2}\right] \mathrm{Cl} 2$ as a white powder (106 mg, 81\%). Found: C, 32.88; H, 3.66; N, 17.10\% $\mathrm{AuC}_{18} \mathrm{H}_{24} \mathrm{~N}_{8} \mathrm{Cl}_{3}$ requires C, 32.97; H, 3.69; N, $17.09 \% .{ }^{1} \mathrm{H}$ NMR $\left(600.13 \mathrm{MHz}\right.$, DMSO- $\left.d_{6}\right): \delta 8.09\left(\mathrm{~d},{ }^{2} J_{\mathrm{H}, \mathrm{H}} 15.3 \mathrm{~Hz}, 2 \mathrm{H}, \mathrm{CHH}\right)$, $8.03\left(\mathrm{~d},{ }^{3} J_{\mathrm{H}, \mathrm{H}} 2.1 \mathrm{~Hz}, 4 \mathrm{H}\right.$, imidazolyl H4/H5), $7.77\left(\mathrm{~d},{ }^{3} J_{\mathrm{H}, \mathrm{H}} 2.1\right.$ $\mathrm{Hz}, 4 \mathrm{H}$, imidazolyl H4/H5), 6.79 (d, ${ }^{2} J_{\mathrm{H}, \mathrm{H}} 15.3 \mathrm{~Hz}, 2 \mathrm{H}, \mathrm{CH} H$ ), $3.69\left(\mathrm{~s}, 12 \mathrm{H}, 4 \times \mathrm{CH}_{3}\right) .{ }^{13} \mathrm{C}\left\{{ }^{1} \mathrm{H}\right\}$ NMR (150.9 MHz, DMSO- $\left.d_{6}\right)$ : $\delta 146.82$ (NCN), 124.96 (imidazolyl C4/C5), 123.63 (imidazolyl C4/C5), $63.15\left(\mathrm{CH}_{2}\right), 37.78\left(\mathrm{CH}_{3}\right)$. HRMS $\left(\mathrm{ESI}^{+}\right)$: calcd for $\mathrm{AuC}_{18} \mathrm{H}_{24} \mathrm{~N}_{8} \mathrm{Cl}_{2}^{+}\left(\left[\mathrm{AuL}^{1} \mathrm{Cl}_{2}\right]^{+}\right), \quad m / \mathrm{z}$ 619.1166. Found, $m / z$ 619.1160 .

Complex 5, $\left[\mathbf{A u}\left(\mathbf{L}^{1}\right)_{2}\right]\left(\mathbf{P F}_{6}\right)_{3}$. A solution of $\mathrm{KPF}_{6}(106 \mathrm{mg}$, $0.58 \mathrm{mmol})$ in water $(3 \mathrm{~mL})$ was added to a solution of $\left[\mathrm{Au}\left(\mathbf{L}^{\mathbf{1}}\right)_{2} \mathrm{Cl}_{2}\right] \mathrm{Cl} 2$ (106 mg, $\left.0.17 \mathrm{mmol}\right)$ in $\mathrm{MeOH}(10 \mathrm{~mL})$. The resulting precipitate was collected by filtration and washed with water and $(3 \times 3 \mathrm{~mL})$ with methanol to leave $\left[\mathrm{Au}\left(\mathbf{L}^{1}\right)_{2}\right]$ $\left(\mathrm{PF}_{6}\right)_{3} 5$ as a white powder (93 mg, 59\%). Found: C, 21.88; $\mathrm{H}, 2.57 ; \mathrm{N}, 11.43 \% \mathrm{AuC}_{18} \mathrm{H}_{24} \mathrm{~N}_{8} \mathrm{P}_{3} \mathrm{~F}_{18}$ requires C, 21.96; $\mathrm{H}, 2.46$; $\mathrm{N}, 11.38 \% .{ }^{1} \mathrm{H}$ NMR $\left(600.13 \mathrm{MHz}\right.$, DMSO- $\left.d_{6}\right): \delta 8.01\left(\mathrm{~d},{ }^{3} J_{\mathrm{H}, \mathrm{H}}\right.$ $1.8 \mathrm{~Hz}, 4 \mathrm{H}$, imidazolyl H4/H5), $7.77\left(\mathrm{~d},{ }^{3} J_{\mathrm{H}, \mathrm{H}} 1.8 \mathrm{~Hz}, 4 \mathrm{H}\right.$, imidazolyl H4/H5), 6.84 (d, $\left.{ }^{2} J_{\mathrm{H}, \mathrm{H}} 13.2 \mathrm{~Hz}, 2 \mathrm{H}, \mathrm{CHH}\right), 6.75$ (d, ${ }^{2} J_{\mathrm{H}, \mathrm{H}}$ $13.2 \mathrm{~Hz}, 2 \mathrm{H}, \mathrm{CHH}$ ), 3.50 (s, $\left.12 \mathrm{H}, 4 \times \mathrm{CH}_{3}\right) .{ }^{13} \mathrm{C}\left\{{ }^{1} \mathrm{H}\right\} \mathrm{NMR}$ (150.9 MHz, DMSO- $d_{6}$ ): $\delta 146.68$ (NCN), 125.16 (imidazolyl C4/C5), 124.28 (imidazolyl C4/C5), $63.09\left(\mathrm{CH}_{2}\right), 37.83\left(\mathrm{CH}_{3}\right)$. 
HRMS (ESI $\left.{ }^{+}\right)$: calcd for $\mathrm{AuC}_{18} \mathrm{H}_{24} \mathrm{~N}_{8} \mathrm{P}_{2} \mathrm{~F}_{12}{ }^{+}\left(\left[\mathrm{Au}\left(\mathbf{L}^{\mathbf{1}}\right)_{2} \cdot 2 \mathrm{PF}_{6}\right]^{+}\right), \mathrm{m} / \mathrm{z}$ 839.1073. Found: $m / z$ 839.1071.

Complex 3, $\left[\mathrm{Au}\left(\mathrm{L}^{2}\right)_{2} \mathrm{Cl}_{2}\right] \mathrm{Cl}$. A solution of LiOAc $(61 \mathrm{mg}$, $0.92 \mathrm{mmol}$ ) in DMF $(5 \mathrm{~mL})$ was added to a solution of the bis (imidazolium) salt $\mathbf{L}^{2} \cdot 2 \mathrm{HCl}(105 \mathrm{mg}, 0.40 \mathrm{mmol})$ and $\mathrm{KAuCl}_{4}$ $(75 \mathrm{mg}, 0.20 \mathrm{mmol})$ in DMF $(10 \mathrm{~mL})$ at $80^{\circ} \mathrm{C}$. The mixture was then heated to $110{ }^{\circ} \mathrm{C}$ and maintained at that temperature overnight. The white precipitate that formed was collected by filtration and washed successively with DMF, acetone, and $\mathrm{Et}_{2} \mathrm{O}$, to leave $\left[\mathrm{Au}\left(\mathbf{L}^{2}\right)_{2} \mathrm{Cl}_{2}\right] \mathrm{Cl} 3$ as a white powder $(108 \mathrm{mg}$, $79 \%$ ). Found: $\mathrm{C}, 35.32 ; \mathrm{H}, 4.33 ; \mathrm{N}, 16.05 \% \mathrm{AuC}_{20} \mathrm{H}_{28} \mathrm{~N}_{8} \mathrm{Cl}_{3}$ requires C, 35.13; H, 4.13; N, $16.39 \% .{ }^{1} \mathrm{H}$ NMR $(600.13 \mathrm{MHz}$, DMSO- $\left.d_{6}\right): \delta 7.86\left(\mathrm{~d},{ }^{3} J_{\mathrm{H}, \mathrm{H}} 2.1 \mathrm{~Hz}, 4 \mathrm{H}\right.$, imidazolyl H4/H5), 7.73 (d, ${ }^{3} \mathrm{H}_{\mathrm{H}, \mathrm{H}} 2.1 \mathrm{~Hz}, 4 \mathrm{H}$, imidazolyl H4/H5), $5.46\left(\mathrm{~m}, 4 \mathrm{H}, \mathrm{CH}_{2} \mathrm{CH}_{2}\right.$ ), $4.91\left(\mathrm{~m}, 4 \mathrm{H}, \mathrm{CH}_{2} \mathrm{CH}_{2}\right), 3.35\left(\mathrm{~s}, 12 \mathrm{H}, 4 \times \mathrm{CH}_{3}\right) .{ }^{13} \mathrm{C}\left\{{ }^{1} \mathrm{H}\right\} \mathrm{NMR}$ (150.9 MHz, DMSO- $d_{6}$ ): $\delta 144.58$ (NCN), 126.47 (imidazolyl C4/ C5), 125.13 (imidazolyl C4/C5), $47.64\left(\mathrm{CH}_{2} \mathrm{CH}_{2}\right), 38.01\left(\mathrm{CH}_{3}\right)$. HRMS $\left(\mathrm{ESI}^{+}\right)$: calcd for $\mathrm{AuC}_{20} \mathrm{H}_{28} \mathrm{~N}_{8} \mathrm{Cl}_{2}^{+}\left(\left[\mathrm{Au}\left(\mathbf{L}^{2}\right)_{2} \mathrm{Cl}_{2}\right]^{+}\right) \mathrm{m} / \mathrm{z}$ 647.1479. Found, $m / z$ 647.1464.

Complex 6, $\left[\mathbf{A u}\left(\mathbf{L}^{2}\right)_{2}\right]\left(\mathbf{P F}_{6}\right)_{3}$. This compound was prepared in the same way as $\left[\mathrm{Au}\left(\mathbf{L}^{\mathbf{1}}\right)_{2}\right]\left(\mathrm{PF}_{6}\right)_{3} \mathbf{5}$, and was obtained in $69 \%$ yield. Found: $\mathrm{C}, \quad 23.13 ; \mathrm{H}, \quad 3.30 ; \quad \mathrm{N}, \quad 10.80 \%$ $\mathrm{AuC}_{20} \mathrm{H}_{28} \mathrm{~N}_{8} \mathrm{P}_{3} \mathrm{~F}_{18} \cdot\left(\mathrm{H}_{2} \mathrm{O}\right)$ requires C, $23.31 ; \mathrm{H}, 2.93 ; \mathrm{N}, 10.88 \%$. ${ }^{1} \mathrm{H}$ NMR (600.13 MHz, DMSO- $\left.d_{6}\right): \delta 7.84\left(\mathrm{~d},{ }^{3} J_{\mathrm{H}, \mathrm{H}} 1.8 \mathrm{~Hz}, 4 \mathrm{H}\right.$, imidazolyl H4/H5), $7.71\left(\mathrm{~d},{ }^{3} J_{\mathrm{H}, \mathrm{H}} 1.8 \mathrm{~Hz}, 4 \mathrm{H}\right.$, imidazolyl $\mathrm{H} 4 / \mathrm{H} 5), 5.30\left(\mathrm{~m}, 4 \mathrm{H}, \mathrm{CH}_{2} \mathrm{CH}_{2}\right), 4.93\left(\mathrm{~m}, 4 \mathrm{H}, \mathrm{CH}_{2} \mathrm{CH}_{2}\right), 3.30$ (s, $\left.12 \mathrm{H}, 4 \times \mathrm{CH}_{3}\right) \cdot{ }^{13} \mathrm{C}\left\{{ }^{1} \mathrm{H}\right\}$ NMR (150.9 MHz, DMSO- $\left.d_{6}\right)$ : $\delta 145.14$ (NCN), 127.05 (imidazolyl C4/C5), 125.76 (imidazolyl C4/C5), $47.92\left(\mathrm{CH}_{2} \mathrm{CH}_{2}\right), 38.19\left(\mathrm{CH}_{3}\right)$. HRMS $\left(\mathrm{ESI}^{+}\right)$: calcd for $\mathrm{AuC}_{20} \mathrm{H}_{28} \mathrm{~N}_{8} \mathrm{P}_{2} \mathrm{~F}_{12}{ }^{+}\left(\left[\mathrm{Au}\left(\mathbf{L}^{2}\right)_{2} \cdot 2 \mathrm{PF}_{6}\right]^{+}\right) \mathrm{m} / z$ 867.1386. Found, $m / z$ 867.1344.

Complex 4, $\left[\mathrm{AuL}^{3} \mathrm{Cl}_{2}\right] \mathrm{Cl}$. A solution of LiOAc $(20 \mathrm{mg}$, $0.30 \mathrm{mmol})$ in DMF $(5 \mathrm{~mL})$ added to a solution of the tetra (imidazolium) salt $\mathbf{L}^{3} \cdot 4 \mathrm{HCl}(54 \mathrm{mg}, 0.083 \mathrm{mmol})$ and $\mathrm{KAuCl}_{4}$ $(32 \mathrm{mg}, 0.083 \mathrm{mmol})$ in DMF $(10 \mathrm{~mL})$ at $80{ }^{\circ} \mathrm{C}$ and this temperature was maintained for overnight. The white precipitate that formed was collected by filtration and washed successively with DMF, acetone, and $\mathrm{Et}_{2} \mathrm{O}$ to leave $\left[\mathrm{AuL}^{3} \mathrm{Cl}_{2}\right] \mathrm{Cl} \mathbf{4}$ as a white powder (32 mg, 48\%). Found: C, 44.65; H, 3.52; N, 13.83\% $\mathrm{AuC}_{30} \mathrm{H}_{28} \mathrm{~N}_{8} \mathrm{Cl}_{3}$ requires C, 44.82; $\mathrm{H}, 3.51 ; \mathrm{N}, 13.94 \% .{ }^{1} \mathrm{H}$ NMR (600.13 MHz, DMSO- $\left.d_{6}\right): \delta 7.97\left(\mathrm{~d},{ }^{3} J_{\mathrm{H}, \mathrm{H}} 2.1 \mathrm{~Hz}, 4 \mathrm{H}\right.$, imidazolyl $\mathrm{H} 4 / \mathrm{H} 5), 7.68,7.52\left(\mathrm{~m}, 8 \mathrm{H}, \mathrm{C}_{6} \mathrm{H}_{4}\right), 7.48\left(\mathrm{~d},{ }^{2} J_{\mathrm{H}, \mathrm{H}} 12.6 \mathrm{~Hz}, 2 \mathrm{H}\right.$, $\mathrm{C} H \mathrm{H}), 7.42\left(\mathrm{~d},{ }^{3} J_{\mathrm{H}, \mathrm{H}} 2.1 \mathrm{~Hz}, 4 \mathrm{H}\right.$, imidazolyl H4/H5), 6.78 (d, $\left.{ }^{2} J_{\mathrm{H}, \mathrm{H}} 12.6 \mathrm{~Hz}, 2 \mathrm{H}, \mathrm{CH} H\right), 5.26\left(\mathrm{~d},{ }^{2} J_{\mathrm{H}, \mathrm{H}} 15.6 \mathrm{~Hz}, 4 \mathrm{H}\right.$, benzylic $\mathrm{CHH}), 5.15\left(\mathrm{~d},{ }^{2} J_{\mathrm{H}, \mathrm{H}} 15.6 \mathrm{~Hz}, 4 \mathrm{H}\right.$, benzylic, $\left.\mathrm{CH} H\right) .{ }^{13} \mathrm{C}\left\{{ }^{1} \mathrm{H}\right\} \mathrm{NMR}$ (150.9 MHz, DMSO- $\left.d_{6}\right): \delta 145.92(\mathrm{NCN}), 134.96\left(\mathrm{C}_{6} \mathrm{H}_{4}\right), 132.20$ $\left(\mathrm{C}_{6} \mathrm{H}_{4}\right), 129.70\left(\mathrm{C}_{6} \mathrm{H}_{4}\right), 125.11$ (imidazolyl C4/C5), 123.73 (imidazolyl C4/C5), $62.20\left(\mathrm{CH}_{2}\right), 52.64$ (benzylic $\left.\mathrm{CH}_{2}\right)$. HRMS (ESI ${ }^{+}$): calcd for $\mathrm{AuC}_{30} \mathrm{H}_{28} \mathrm{~N}_{8} \mathrm{Cl}_{2}^{+}\left(\left[\mathrm{AuL}^{3} \mathrm{Cl}_{2}\right]^{+}\right) \mathrm{m} / z$ 767.1479. Found, $m / z 767.1469$.

Complex 7, $\left[\mathrm{AuL}^{3}\right]\left(\mathbf{P F}_{6}\right)_{3}$. This compound was prepared in the same way as $\left[\mathrm{Au}\left(\mathbf{L}^{\mathbf{1}}\right)_{2}\right]\left(\mathrm{PF}_{6}\right)_{3} \mathbf{5}$, and was obtained in $72 \%$ yield. Found: C, 31.90; H, 2.39; N, 9.73\% $\mathrm{AuC}_{30} \mathrm{H}_{28} \mathrm{~N}_{8} \mathrm{P}_{3} \mathrm{~F}_{18}$ requires C, $31.82 ; \mathrm{H}, 2.49 ; \mathrm{N}, 9.89 \% .{ }^{1} \mathrm{H}$ NMR $\left(600.13 \mathrm{MHz}\right.$, DMSO- $\left.d_{6}\right): \delta 7.98$ (d, ${ }^{3} J_{\mathrm{H}, \mathrm{H}} 1.8 \mathrm{~Hz}, 4 \mathrm{H}$, imidazolyl H4/H5), 7.69, 7.56 (m, 8H, $\mathrm{C}_{6} \mathrm{H}_{4}$ ), $7.44\left(\mathrm{~d},{ }^{3} J_{\mathrm{H}, \mathrm{H}} 1.8 \mathrm{~Hz}, 4 \mathrm{H}\right.$, imidazolyl H4/H5), 6.82 (d, ${ }^{2} J_{\mathrm{H}, \mathrm{H}} 13.2$
$\mathrm{Hz}, 2 \mathrm{H}, \mathrm{CHH}), 6.72\left(\mathrm{~d},{ }^{2} J_{\mathrm{H}, \mathrm{H}} 13.2 \mathrm{~Hz}, 2 \mathrm{H}, \mathrm{CH} H\right), 5.34\left(\mathrm{~d},{ }^{2} J_{\mathrm{H}, \mathrm{H}}\right.$ $15.3 \mathrm{~Hz}, 4 \mathrm{H}$, benzylic $\mathrm{C} H \mathrm{H}$ ), $5.00\left(\mathrm{~d},{ }^{2} J_{\mathrm{H}, \mathrm{H}} 15.3 \mathrm{~Hz}, 4 \mathrm{H}\right.$, benzylic $\mathrm{CH} H) .{ }^{13} \mathrm{C}\left\{{ }^{1} \mathrm{H}\right\}$ NMR (150.9 MHz, DMSO- $\left.d_{6}\right): \delta 146.21$ (NCN), $134.86\left(\mathrm{C}_{6} \mathrm{H}_{4}\right), 132.20\left(\mathrm{C}_{6} \mathrm{H}_{4}\right), 129.86\left(\mathrm{C}_{6} \mathrm{H}_{4}\right), 125.86$ (imidazolyl C4/C5), 124.21 (imidazolyl C4/C5), $62.24\left(\mathrm{CH}_{2}\right), 52.32$ (benzylic $\left.\mathrm{CH}_{2}\right)$. HRMS $\left(\mathrm{ESI}^{+}\right)$: calcd for $\mathrm{AuC}_{30} \mathrm{H}_{28} \mathrm{~N}_{8} \mathrm{P}_{2} \mathrm{~F}_{12}{ }^{+}\left(\left[\mathrm{AuL}^{3} \cdot 2 \mathrm{PF}_{6}\right]^{+}\right)$ $\mathrm{m} / \mathrm{z}$ 987.1386. Found, $\mathrm{m} / \mathrm{z}$ 987.1396.

\section{X-Ray crystal structure determinations}

Crystals of $\left[\mathrm{Au}\left(\mathbf{L}^{\mathbf{1}}\right)_{2}\right]\left(\mathrm{PF}_{6}\right)_{3} \cdot(\mathrm{MeCN})_{2} \quad \mathbf{5} \cdot(\mathrm{MeCN})_{2}, \quad\left[\mathrm{Au}\left(\mathbf{L}^{2}\right)_{2}\right]-$ $\left(\mathrm{PF}_{6}\right)_{3} \cdot(\mathrm{MeCN})_{2} \mathbf{6} \cdot(\mathrm{MeCN})_{2}$ and $\left[\mathrm{AuL}^{3}\right]\left(\mathrm{PF}_{6}\right)_{3} \cdot(\mathrm{MeCN})_{3} 7 \cdot(\mathrm{MeCN})_{3}$ were grown by diffusion of vapours between neat diethyl ether and a solution of the complex in acetonitrile, and crystals of $\left[\mathrm{Au}\left(\mathbf{L}^{\mathbf{1}}\right)_{2} \mathrm{Cl}_{2}\right] \mathrm{Cl} \cdot(\mathrm{MeOH})_{2} \quad 2 \cdot(\mathrm{MeOH})_{2}, \quad\left[\mathrm{Au}\left(\mathbf{L}^{2}\right)_{2} \mathrm{Cl}_{2}\right] \mathrm{Cl} \cdot(\mathrm{MeOH})$ 3. $(\mathrm{MeOH})$ and $\left[\mathrm{AuL}^{3} \mathrm{Cl}_{2}\right] \mathrm{Cl} \cdot(\mathrm{MeOH})_{3.5} \mathbf{4} \cdot(\mathrm{MeOH})_{3.5}$ were grown by diffusion of vapours between neat diethyl ether and a solution of the complex in methanol. Crystallographic data were collected at 100(2) K on either an Oxford Diffraction Gemini or

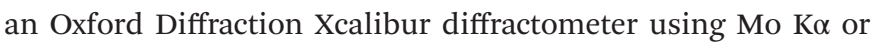
$\mathrm{Cu} \mathrm{K} \alpha$ radiation. Following analytical absorption corrections and solution by direct methods, the structures were refined against $F^{2}$ with full-matrix least-squares using the program SHELXL-2014. ${ }^{58}$ Unless stated differently below, all hydrogen atoms were added at calculated positions and refined by use of riding models with isotropic displacement parameters based on those of the parent atoms. Except for those atoms mentioned below, anisotropic displacement parameters were employed throughout for the non-hydrogen atoms. For the structure of $\left[\mathrm{AuL}^{3} \mathrm{Cl}_{2}\right] \mathrm{Cl} \cdot(\mathrm{MeOH})_{3.5} \mathbf{4} \cdot(\mathrm{MeOH})_{3.5}$, one chlorido ligand was modelled as being disordered with a molecule of methanol with site occupancies constrained to 0.75 and 0.25 from trial refinement and as required for charge balance. Remaining solvent molecules were modelled as three molecules of methanol situated on a crystallographic mirror plane. Geometries and displacement parameters of the solvent were restrained to reasonable values. Solvent hydrogen atoms were not included in the model. For the structure of $\left[\mathrm{Au}\left(\mathbf{L}^{\mathbf{1}}\right)_{2}\right]$ $\left(\mathrm{PF}_{6}\right)_{3} \cdot(\mathrm{MeCN})_{2} \mathbf{5} \cdot(\mathrm{MeCN})_{2}$, the solvent acetonitrile molecule was found to be disordered over two sites with the methyl atom common to both components. In $\left[\mathrm{Au}\left(\mathbf{L}^{2}\right)_{2}\right]\left(\mathrm{PF}_{6}\right)_{3} \cdot(\mathrm{MeCN})_{2}$ 6. $(\mathrm{MeCN})_{2}$, the ligand and one hexafluorophosphate anion are both disordered over two sets of sites with occupancies refined to $0.765(4)$ and its complement after trial refinement showed no significant differences in the refined values. The atoms of the minor component of the cation were refined with isotropic displacement parameters. The remaining hexafluorophosphate anion was modelled as being rotationally disordered with site occupancies were constrained to 0.5 after trial refinement. The solvent was modelled as acetonitrile, disordered over two sets of sites. For the structure of $\left[\mathrm{AuL}^{3}\right]\left(\mathrm{PF}_{6}\right)_{3} \cdot(\mathrm{MeCN})_{3} 7 \cdot(\mathrm{MeCN})_{3}$, the fluorine atoms of two hexafluorophosphate anions were modelled as being disordered over two sites; hexafluorophosphate anion (1) where site occupancies were refined to 0.75(2) and its complement and hexafluorophosphate anion (3) where fluorine occupancies were constrained to 0.5 after trial refinement. 


\section{Acknowledgements}

The authors acknowledge the facilities, and the scientific and technical assistance of the Australian Microscopy \& Microanalysis Research Facility at the Centre for Microscopy, Characterisation \& Analysis, The University of Western Australia. Ahmed H. Mageed thanks The Higher Committee for Education Development in Iraq (HCED) for financial support.

\section{References}

1 P. J. Barnard, M. V. Baker, S. J. Berners-Price, B. W. Skelton and A. H. White, Dalton Trans., 2004, 1038-1047.

2 M. P. Rigobello, A. Folda, B. Dani, R. Menabò, G. Scutari and A. Bindoli, Eur. J. Pharmacol., 2008, 582, 26-34.

3 W. Liu and R. Gust, Chem. Soc. Rev., 2013, 42, 755-773.

4 D. Pflästerer and A. S. K. Hashmi, Chem. Soc. Rev., 2016, 45, 1331-1367.

$5 \mathrm{H}$. Schmidbaur and A. Schier, in Comprehensive Organometallic Chemistry III, ed. R. H. Crabtree and D. M. P. Mingos, Elsevier, Oxford UK, 2007, vol. 2, pp. 252-308.

6 T. Zou, C. T. Lum, C.-N. Lok, J.-J. Zhang and C.-M. Che, Chem. Soc. Rev., 2015, 44, 8786-8801.

7 I. J. Lin and C. S. Vasam, Can. J. Chem., 2005, 83, 812-825.

8 M. Baron, C. Tubaro, M. Basato, A. Biffis, M. M. Natile and C. Graiff, Organometallics, 2011, 30, 4607-4615.

9 P. de Frémont, R. Singh, E. D. Stevens, J. L. Petersen and S. P. Nolan, Organometallics, 2007, 26, 1376-1385.

10 S. Zhu, R. Liang and H. Jiang, Tetrahedron, 2012, 68, 79497955.

11 I. G. Santos, A. Hagenbach and U. Abram, Dalton Trans., 2004, 677-682.

12 S. D. Khanye, N. B. Báthori, G. S. Smith and K. Chibale, Dalton Trans., 2010, 39, 2697-2700.

13 R. Jothibasu, H. V. Huynh and L. L. Koh, J. Organomet. Chem., 2008, 693, 374-380.

14 S. Gaillard, A. M. Z. Slawin, A. T. Bonura, E. D. Stevens and S. P. Nolan, Organometallics, 2009, 29, 394-402.

15 M. C. Jahnke, T. Pape and F. E. Hahn, Z. Anorg. Allg. Chem., 2010, 636, 2309-2314.

16 M. Pažický, A. Loos, M. J. Ferreira, D. Serra, N. Vinokurov, F. Rominger, C. Jäkel, A. S. K. Hashmi and M. Limbach, Organometallics, 2010, 29, 4448-4458.

17 C. Hirtenlehner, C. Krims, J. Hölbling, M. List, M. Zabel, M. Fleck, R. J. Berger, W. Schoefberger and U. Monkowius, Dalton Trans., 2011, 40, 9899-9910.

18 S. Gaillard, X. Bantreil, A. M. Slawin and S. P. Nolan, Dalton Trans., 2009, 6967-6971.

19 M. Kriechbaum, D. Otte, M. List and U. Monkowius, Dalton Trans., 2014, 43, 8781-8791.

20 A. Collado, J. Bohnenberger, M. J. Oliva-Madrid, P. Nun, D. B. Cordes, A. M. Slawin and S. P. Nolan, Eur. J. Inorg. Chem., 2016, 2016, 4111-4122.
21 J. Gil-Rubio, V. Cámara, D. Bautista and J. Vicente, Inorg. Chem., 2013, 52, 4071-4083.

22 W. Liu, K. Bensdorf, M. Proetto, A. Hagenbach, U. Abram and R. Gust, J. Med. Chem., 2012, 55, 3713-3724.

23 H. Sivaram, J. Tan and H. V. Huynh, Organometallics, 2012, 31, 5875-5883.

24 C. Topf, C. Hirtenlehner, M. Zabel, M. List, M. Fleck and U. Monkowius, Organometallics, 2011, 30, 2755-2764.

25 M. Muuronen, J. E. Perea-Buceta, M. Nieger, M. Patzschke and J. Helaja, Organometallics, 2012, 31, 4320-4330.

26 J. P. Reeds, A. C. Whitwood, M. P. Healy and I. J. Fairlamb, Organometallics, 2013, 32, 3108-3120.

27 C. Topf, C. Hirtenlehner, M. Fleck, M. List and U. Monkowius, Z. Anorg. Allg. Chem., 2011, 637, 2129-2134.

28 C. Hemmert, R. Poteau, M. Laurent and H. Gornitzka, J. Organomet. Chem., 2013, 745, 242-250.

29 F. dit Dominique, H. Gornitzka, A. Sournia-Saquet and C. Hemmert, Dalton Trans., 2009, 340-352.

30 M. Baron, C. Tubaro, M. Basato, A. A. Isse, A. Gennaro, L. Cavallo, C. Graiff, A. Dolmella, L. Falivene and L. Caporaso, Chem. - Eur. J., 2016, 22, 10211-10224.

31 C. Tubaro, M. Baron, M. Costante, M. Basato, A. Biffis, A. Gennaro, A. A. Isse, C. Graiff and G. Accorsi, Dalton Trans., 2013, 42, 10952-10963.

32 Z. Lu, S. A. Cramer and D. M. Jenkins, Chem. Sci., 2012, 3, 3081-3087.

33 G. Marangoni, B. Pitteri, V. Bertolasi, G. Gilli and V. Ferretti, J. Chem. Soc., Dalton Trans., 1986, 1941-1944.

34 V. Duckworth and N. Stephenson, Inorg. Chem., 1969, 8, 1661-1664.

35 H. V. Huynh, S. Guo and W. Wu, Organometallics, 2013, 32, 4591-4600.

36 G. Nardin, L. Randaccio, G. Annibale, G. Natile and B. Pitteri, J. Chem. Soc., Dalton Trans., 1980, 220-223.

37 L. S. Hollis and S. J. Lippard, J. Am. Chem. Soc., 1983, 105, 4293-4299.

38 M. P. Suh, I. S. Kim, B. Y. Shim, D. Hong and T.-S. Yoon, Inorg. Chem., 1996, 35, 3595-3598.

39 S. Alvarez, Dalton Trans., 2013, 42, 8617-8636.

40 R. Elder and J. Watkins, Inorg. Chem., 1986, 25, 223-226.

41 H. Isci and W. R. Mason, Inorg. Chem., 1983, 22, 22662272.

42 S. Ramalingam and S. Soundararajan, J. Inorg. Nucl. Chem., 1967, 29, 1763-1768.

43 W. J. Geary, Coord. Chem. Rev., 1971, 7, 81-122.

44 C. B. Aakeröy, T. A. Evans, K. R. Seddon and I. Pálinkó, New J. Chem., 1999, 23, 145-152.

45 B. Jacques, D. Hueber, S. Hameury, P. Braunstein, P. Pale, A. 1. Blanc and P. de Frémont, Organometallics, 2014, 33, 2326-2335.

46 J. L. Hickey, PhD thesis, The University of Western Australia, 2008.

47 M. Baron, C. Tubaro, M. Basato, A. Biffis and C. Graiff, J. Organomet. Chem., 2012, 714, 41-46.

48 J. L. Wong and J. H. Keck Jr., J. Org. Chem., 1974, 39, 23982403. 
49 Y. Takeuchi, H. J. Yeh, K. L. Kirk and L. A. Cohen, J. Org. Chem., 1978, 43, 3565-3570.

50 C. Hardacre, J. D. Holbrey and S. J. McMath, Chem. Commun., 2001, 367-368.

51 M. V. Baker, B. W. Skelton, A. H. White and C. C. Williams, Organometallics, 2002, 21, 2674-2678.

52 M. V. Baker, M. J. Bosnich, D. H. Brown, L. T. Byrne, V. J. Hesler, B. W. Skelton, A. H. White and C. C. Williams, J. Org. Chem., 2004, 69, 7640-7652.

53 M. V. Baker, D. H. Brown, C. H. Heath, B. W. Skelton, A. H. White and C. C. Williams, J. Org. Chem., 2008, 73, 9340-9352.
54 M. Baron, C. Tubaro, A. Biffis, M. Basato, C. Graiff, A. Poater, L. Cavallo, N. Armaroli and G. Accorsi, Inorg. Chem., 2012, 51, 1778-1784.

55 Y. Unger, A. Zeller, M. A. Taige and T. Strassner, Dalton Trans., 2009, 4786-4794.

56 O. Sanchez, S. González, M. Fernández, A. R. HigueraPadilla, Y. Leon, D. Coll, A. Vidal, P. Taylor, I. Urdanibia and M. C. Goite, Inorg. Chim. Acta, 2015, 437, 143-151.

57 T. Pape and F. E. Hahn, Dalton Trans., 2013, 42, 73307337.

58 G. M. Sheldrick, Acta Crystallogr., Sect. C: Struct. Chem., 2015, 71, 3-8. 